\title{
norden
}

\section{Mining in the Nordic Countries}

A comparative review of legislation and taxation

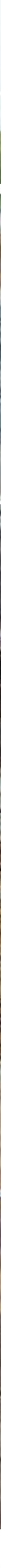

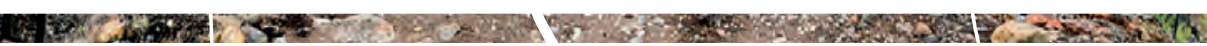



2 norden 



\section{Mining in the Nordic Countries}

A comparative review of legislation and taxation

Petter Hojem

TemaNord 2015:542 
Mining in the Nordic Countries

A comparative review of legislation and taxation

Petter Hojem

ISBN 978-92-893-4232-2 (PRINT)

ISBN 978-92-893-4234-6 (PDF)

ISBN 978-92-893-4233-9 (EPUB)

http://dx.doi.org/10.6027/TN2015-542

TemaNord 2015:542

ISSN 0908-6692

(C) Nordic Council of Ministers 2015

Layout: Hanne Lebech

Cover photo: ImageSelect

Print: Rosendahls-Schultz Grafisk

Copies: 200

Printed in Denmark

This publication has been published with financial support by NordMin - A Nordic Network of Expertise for a Sustainable Mining and Mineral Industry, funded by the Nordic Council of Ministers. However, the contents of this publication do not necessarily reflect the views, policies or recommendations of the Nordic Council of Ministers.

\section{www.norden.org/nordpub}

\section{Nordic co-operation}

Nordic co-operation is one of the world's most extensive forms of regional collaboration, involving Denmark, Finland, Iceland, Norway, Sweden, and the Faroe Islands, Greenland, and Åland.

Nordic co-operation has firm traditions in politics, the economy, and culture. It plays an important role in European and international collaboration, and aims at creating a strong Nordic community in a strong Europe.

Nordic co-operation seeks to safeguard Nordic and regional interests and principles in the global community. Common Nordic values help the region solidify its position as one of the world's most innovative and competitive.

\section{Nordic Council of Ministers}

Ved Stranden 18

DK-1061 Copenhagen $\mathrm{K}$

Phone (+45) 33960200

\section{www.norden.org}




\section{Contents}

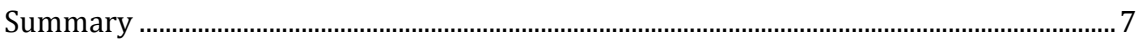

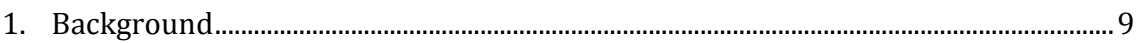

1.1 Focus, limitations and organisation of study .....................................................

2. Comparative review of legal frameworks in the Nordic countries ...........................11

2.1 Mineral and mining laws ..................................................................................12

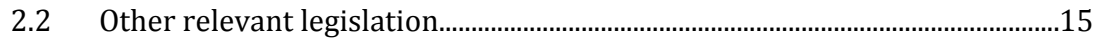

3. Individual country mining and mineral legislation review …...................................19

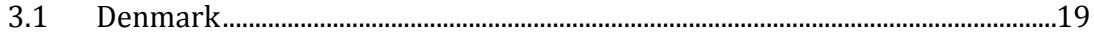

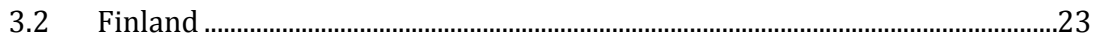

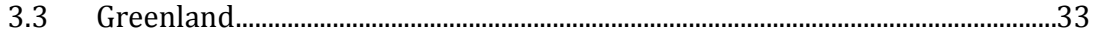

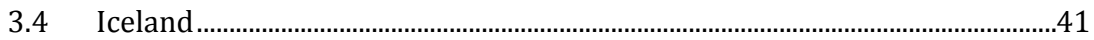

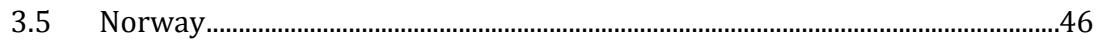

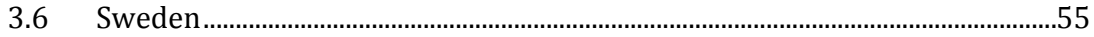

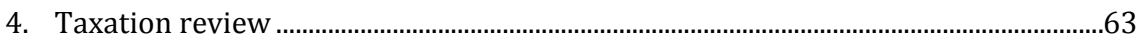

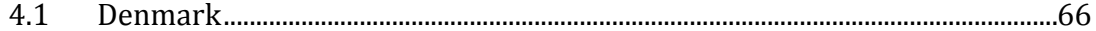

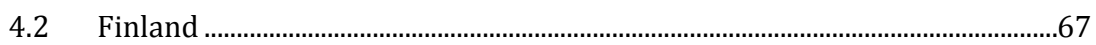

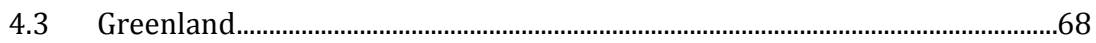

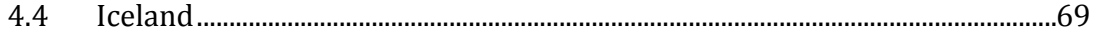

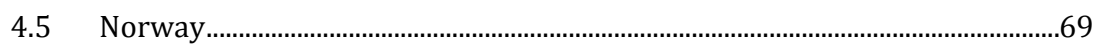

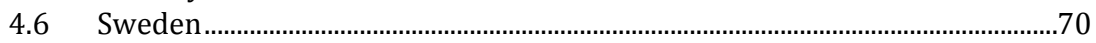

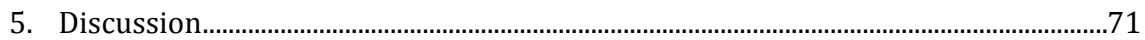

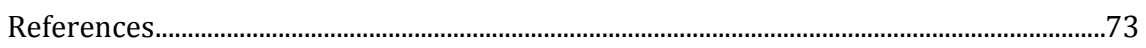

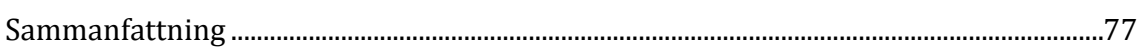

Appendix A. Taxation table ..............................................................................................79 



\section{Summary}

The last few years have seen a lot of activity within the Nordic mining industry. New mines have opened, but there have also been cases of bankruptcies. Heightened activity has in turn led to discussions on the role of legislation and taxation in ensuring that mining contributes to sustainable development. At the same time, a number of voluntary sustainability initiatives have appeared. The aim of this report is to give an overview of legislation and taxation concerning the Nordic mining industry.

For historic reasons, the Nordic countries share a lot of similarities in legislation. And not least with regards to environmental laws, the EU has contributed to further harmonisation, even among the non-member states Iceland and Norway. Yet important differences exist. Legal revisions are sometimes the result of much-publicised problems, so experiences in each country play an important role. For example, Norway gives its Sami population and municipalities a stronger say. The Finnish Mining Act includes provisions for mandatory mine safety permits. Denmark and Iceland have relatively smaller mineral industries, which is also reflected in the focus of their subsoil raw material laws. Greenland is perhaps the greatest outlier with regards to legal framework. For example, it does not differentiate between landowner and state-owned minerals, and Social Impact Assessments and negotiated Impact Benefit Agreements are standard requirements, unlike in its Nordic neighbours.

An overview of taxation also indicates both similarities and differences: Finland and Sweden are ranked as having among the lowest effective taxes on mining internationally, while the rate in Norway seem to be somewhat higher. Greenland is an outlier here too, with high royalties in a Nordic context. The Greenlandic level is however more comparable to the global median. At the same time, comparisons should be considered with care, as a range of taxes as well as possible tax deductions play an important role in the actual outcome. 



\section{Background}

The last few years have been dramatic for the Nordic mining industry. Surging commodity prices have led to a large increase in exploration and extraction of minerals. In many cases, this has been welcomed locally as a source of new jobs and development opportunities. But it has also sparked conflict, especially in areas where mines potentially compete for land with other sectors and stakeholders. Thus, mining and sustainable development has become a popular and contentious topic for discussion in the Nordic region just like elsewhere.

Mining is the primary source of important metals and minerals for areas ranging from traditional construction to green technology. Yet mining is also associated with a number of negative consequences, such as large quantities of waste, emissions to water and air, and noise. Furthermore, mineral markets are cyclical, and both booms and busts create challenges for both companies and communities. Not least has this been demonstrated more recently as tumbling commodity prices have led to mining companies scaling down or even closing production. Talvivaara Sotkamo in Finland and Northland Resources in Sweden filed for bankruptcy in November and December 2014 respectively. In Norway, there have been layoffs at several mines.

The last few years have seen some development in the legal framework addressing different aspects of mining and sustainability. Examples include changes in taxation regimes and requirements on companies to establish funds for post-closure rehabilitation. From a company perspective, it has become increasingly evident that success is dependent on support from local communities. In other words, companies need a "social licence to operate". At a minimum, this means adhering to legal requirements, although this may not be enough.

\subsection{Focus, limitations and organisation of study}

This pre-study aims to review the legal frameworks regulating mining activities and mining taxation, and how these differ from one another, in the Nordic countries. This is potentially a daunting task. Mining activities can be sorted along a timeline, from prospecting and explora- 
tion, through mine development and thereafter production, to eventually mine closure and after-care. Each phase has its distinct sustainability challenges, and different phases involve different laws. Many issues are not exclusive for extractive industries, but rather involve a broader array of companies. Here, we will focus on what is more specific for the mining sector. Consequently, the legal review will focus especially on mineral and mining laws, and therefore also in particular on the permitting phase.

Further limitations include the following: Firstly, because of the focus on mineral and mining laws, special attention will be on minerals covered by these specific sector laws. This includes metals, but to a more varying degree aggregates and industrial minerals. Secondly, related activities such as smelting and pelletising are generally excluded from this report.

The rest of the pre-study is organised as follows: It starts with a review of the legal frameworks governing mining in the Nordic countries, with a particular focus on mining and mineral laws. Here, it will present some key common traits in how the Nordic mining companies have legislated around this issue, before looking at individual country specificities. After this, a review of current taxation regimes will be presented. Key information on taxation is summed up in a table in appendix A. 


\section{Comparative review of legal frameworks in the Nordic countries}

There are some significant differences between the Nordic countries when it comes to mining. Denmark and Iceland has no current or planned mines, and quarrying plays an overall less significant part of their national economy. For Finland, Norway and Sweden, mining is important, but first and foremost on the regional level. There are no active mines in Greenland today, but mining can potentially play a pivotal role for the country's economy. Greenland also has a more extreme situation with regards to geography and demographics than other Nordic countries. The specifics of each country will be discussed in more detail in the following sections.

At the same time, the Nordic countries also share many common traits in how they govern mining activities. For example, they share legal tradition. Permitting is generally done on a case-by-case assessment. Common concern for the environment has led to a convergence of mining laws; not only in the Nordic region, but globally. ${ }^{1}$ The extensive amount of EU directives in this area illustrates this. Furthermore, Finland, Greenland, Norway and Sweden have all expressed similar political ambitions to promote mining as well as sustainable development. This is reflected by the mineral strategies adopted by each of these countries in recent years.

Here, we will sketch out some of the main, common characteristics of the legal framework around mining activities in the Nordic countries. Point of departure for the analysis is the normal timeline for a mine, which is the same regardless of location: from permitting procedure and mine development, through production to mine closure, aftercare and monitoring. Each phase is associated with different sustaina-

${ }^{1}$ Liedholm Johnson, Eva (2010). Mineral rights: Legal systems governing exploration and exploitation. Stockholm: Royal Institute of Technology, 257. 
bility issues, and also different parts of legislation. This is illustrated in the figure below:

\begin{tabular}{|c|c|c|}
\hline Determining mine impact & Environmental management & Monitoring \\
\hline Land use planning & Ensuring rights of workers & Rehabilitation of land \\
\hline Compensation agreements & Ensuring work safety & Limiting environmental damage \\
\hline Stakeholder consultations & Paying taxes & \\
\hline Setting conditions & Reporting & \\
\hline $\begin{array}{l}\text { Prospecting, exploration, } \\
\text { mine development }\end{array}$ & Production & $\begin{array}{l}\text { Mine closure, rehabilitation } \\
\text { monitoring }\end{array}$ \\
\hline Minerals laws & Tax and accounting laws & Environmental laws \\
\hline Environmental laws & Labour laws & \\
\hline Planning and building laws & Work environment laws & \\
\hline Heritage conservation laws & Discrimination laws & \\
\hline Indigenous rights laws & Environmental laws & \\
\hline
\end{tabular}

As the figure shows, mining activities are bound by a large number of laws, which touch upon different aspects of economic, environmental and social sustainability. The list of issues and laws is not exhaustive. Many of the laws are not specific for mining, but rather apply for environmentally hazardous industries in general, or even for all companies. In this review, we will give extra attention to the permitting phase of mining, and especially mineral and mining laws, as this sets mining apart from other sectors.

\subsection{Mineral and mining laws}

The first steps towards mining are prospecting, exploration and mine development. Permitting procedures are important as this is where competing claims for land, such as mining, nature conservation, tourism, reindeer herding and so forth, are weighed and solved. It is also here that many of the conditions for mining activities are set. Although expressed differently in different countries, the stated overall aim of the procedure is to promote sustainable development.

Several of the Nordic countries' legal frameworks are considered to be very beneficial for promoting mining activities. The Fraser Institute, a Canadian think tank, publishes an annual survey of mining and exploration companies. According to the authors, the survey "is an attempt to 
assess how mineral endowments and public policy factors such as taxation and regulatory uncertainty affect exploration investment". ${ }^{2}$ Inter alia, the respondents are asked to assess their perception of different jurisdictions' mineral policies, and whether these encourage or deter investment. Of the 112 jurisdictions included in 2013, Sweden and Finland received the highest scores of all, while Norway and Greenland ranked as number 10 and 23 respectively. The following year, Finland retained its second place while Sweden, Norway and Greenland came in fourth, 18th and 32nd place respectively. ${ }^{3}$ Denmark and Iceland were not included in the surveys.

The norm is to differentiate between landowner minerals on the one hand, and state-controlled/owned minerals on the other. Among the former are usually industrial minerals such as gravel and sand, whereas the latter commonly include metallic minerals such as iron, copper and gold. Which minerals fall into either group varies slightly between the Nordic countries. Finnish and Swedish laws similarly list a number of elements and minerals which are considered as "mining minerals" and "concession minerals" respectively. The Icelandic Act on the Survey and Utilisation of Ground Resources lists a number of minerals which may be surveyed and utilised by the landowner without a licence. In Norway, state-owned minerals are those with density above $5 \mathrm{~g} / \mathrm{cm}^{3}$. And the Act on the Use of the Danish Subsoil applies to raw materials which have not been subject to private economic exploitation in the country prior to 23 February 1932. Here, Greenland is the exception to the Nordic trend as its Mineral Resources Act does not differentiate between landowner and state-controlled minerals.

Permitting procedures for landowner minerals and state-controlled minerals differ. Exploration for or exploitation of the former can generally be done by the landowner, or by another party through agreement with the landowner, often subject to an environmental permit. Procedure is more elaborate for state-controlled minerals, as a permit is needed regardless of who actually owns the land, and the procedure is done case-by-case. This will be the main focus here.

The first step is prospecting including exploration. In the Nordic countries, limited prospecting is legal for all without a permit within

\footnotetext{
2 Fraser Institute (2015). Fraser Institute Annual Survey of Mining Companies 2014. Vancouver: Fraser Institute, 1.

3 Fraser Institute (2014). Fraser Institute Annual Survey of Mining Companies 2013. Vancouver: Fraser Institute.
} 
certain limitations, following the tradition of Freedom to Roam. In other words, the general public has a right to access certain public or privately owned lands, and can thereby conduct limited prospecting. For more extensive activity and exclusive rights to exploration, a permit is needed, which is granted by a public authority. The exact procedure for obtaining such a permit differs from country to country, but may include e.g. submission of working plans and public information or consultations. An exploration permit usually gives priority to an exploitation permit. Procedure for the latter is more elaborate, involving more documentation and consultation with a larger number of stakeholders. An important part of the exploitation permitting process is to judge whether the mineral deposit in question can be extracted in an economically feasible manner - in other words, economic sustainability.

As the country-specific sections will show, some differences exist in the Nordic countries' mining and minerals legislation. A notable example is the case of Samis in Finland, Norway and Sweden. All three countries recognise the Samis as an indigenous people with particular rights, a fact which is enshrined in their respective constitutions. Yet they differ in how Sami rights and interests are included and reflected in various laws. For example, in both Finland and Norway, the Samis' rights enjoy particular protection in certain areas. In Sweden, reindeer herding is protected in large parts of the country, but only to the same degree as certain other land uses of national interest. Negotiations on a Nordic Sami Convention were initiated in 2011, which may possibly contribute to harmonising rules between Finland, Norway and Sweden, although this has yet to be seen.

Finally, as we will see later, especially Greenland is an outlier in terms of legislation: For example, its Mineral Resources Act includes provisions for prospecting permits and small-scale exploitation licences, unlike the other Nordic countries. Furthermore, Greenland demands that permit applicants conduct not only an Environmental Impact Assessment (EIA), which we will look at next, but also a Social Impact Assessment (SIA). Also, licences are generally contingent on agreement with Greenlandic authorities on an Impact Benefit Agreement (IBA). 


\subsection{Other relevant legislation}

In order to open a mine, and once a mine has opened, companies need to comply with a number of other laws. Notably, a large focus of the mine permitting phase is environmental legislation. This is taken into account through environmental permitting processes by which a number of conditions may be imposed on mining activities, such as limitations on emissions to water, air and land. Mining companies are also required to report on their environmental performance.

The exact structure of environmental legislation varies between the Nordic countries, from a number of different laws in Finland to a consolidated Environmental Code in Sweden. However, provisions are very similar, not least due to the fact that it has been developed and harmonised through EU legislation. ${ }^{4}$ For example, there exists a specific Mining Waste Directive (2006/21/EC). Another example is the environmental permitting process, which is guided by a number of principles: it should be precautionary, solutions should be based on best available technology, and the polluter shall pay for damage caused. These principles among others are reflected in the EU Industrial Emissions Directive (2010/75/EU), which replaced the previous Directive concerning integrated pollution prevention and control (2008/1/EC).

Exploitation activities, and in some cases even exploration, is usually subject to an Environmental Impact Assessment (EIA). The aim of the assessment is to identify and describe possible impacts of activities on their surroundings, including animals, plants and human health. It includes a (pre-project) baseline assessment in order to facilitate planning, mitigation and monitoring. The extent of the EIA varies however depending on what type of mining activity is planned. Usually, mineral exploration does not require as extensive an assessment as for mineral exploitation. Also, there are some differences between countries despite harmonisation through the EU Directive on the Assessment of the Effects of Certain Public and Private Projects on the Environment. This is also known as the EIA directive (2011/92/EU).

\footnotetext{
${ }^{4}$ For an overview of relevant environmental and other legislation on the EU-level, see Scannell, Yvonne (2012). The Regulation of Mining and Mining Waste in the European Union. Washington and Lee Journal of Energy, Climate, and the Environment 177.
} 
Another set of laws which are of importance in the permitting phase focuses on spatial planning. Mineral extraction differs from many other industries by the fact that it can only be conducted in certain places, namely where there is a mineral deposit. At the same time, the same areas may be used for other activities, and one function of planning legislation is therefore to facilitate and improve decision-making.

The planning system of the three Scandinavian countries is compared in a report from 2013, albeit with a focus on housing development. The report states that "[i]n a European administrative and legal context Scandinavian planning systems are characterized by comprehensive planning [...] with relatively strong municipalities, weak regional levels and a strong sectorial interest". ${ }^{5}$ An important difference, however, is that in Norway, spatial planning is conducted on three levels (state, regional, municipal), in Denmark on two (state and regional) and in Sweden on one (municipal). Also, the European Commission has in the past commissioned a report which looks at the relationship between planning and minerals supply. The report, now slightly dated, covers Denmark, Finland, Norway and Sweden, as well as other EU member states. ${ }^{6}$ As the country-specific reviews will show, national planning laws play an important, but different role in most the Nordic countries.

Following permitting, there is obviously a slew of other laws that is of importance with regards to promoting sustainability within the mining sector. Many of these are not specific for mining, but rather apply to companies in general. A few of them will be mentioned here.

Work conditions and work environment has for a very long time been considered an important aspect of sustainability and mining. The Nordic countries are generally characterised by the fact that rights and conditions, such as wages and work hours, are decided through collective bargaining and agreements between labour unions and employer representatives. In some cases, legislation may restrict itself to stipulating minimum rights, if any at all. On the other hand, work environment issues concerning safety are regulated in legislation. Mining is traditionally considered a relatively dangerous profession. In the last decades, the number of accidents and fatalities within the mining sector has fallen

\footnotetext{
5 Fredricsson, Christian \& Sma, Lukas (2013). En granskning av Norges planeringssystem. Skandinavisk detaljplanering i ett internationellt perspektiv. Nordregio report 2013:1. Stockholm: Nordregio, 9.

6 Wagner, Horst et al. (2004). Minerals planning policies and supply practices in Europe. Leoben: Montanuniversität Leoben.
} 
throughout the world. ${ }^{7}$ Nonetheless, mining still faces a number of challenges and there is room for improvement. The Nordic countries have similar legislation with regards to work environment. ${ }^{8}$ For example, Finland, Norway and Sweden have ratified the ILO Safety and Health in Mines Convention of 1995. Here as well, the EU has contributed to harmonisation through directives such as $92 / 85 /$ EEC on safety and health of pregnant workers, 92/91/EEC on the safety and health protection of workers in the mineral-extracting industries and 92/104/EEC on the safety and health protection of workers in surface and underground mineral extracting industries. ${ }^{9}$ These have since been transposed into national laws and regulations.

However, some differences exist. For example, a 2011 study commissioned by the Nordic Council of Ministers has compared legislation and legal practices in the Nordic countries concerning labour inspection. ${ }^{10}$ The report notes that the Nordic countries differ in how labour inspection is organised, and in follow up systems. Penal clauses for breaches of legislation vary from fines up to imprisonment for two years. Furthermore, the Finnish Mining Act stipulates that a mining safety permit is required prior to establishing a mine. This provision is not found in other Nordic countries' mining and mineral legislation.

Reporting, such as through annual reports, is an important tool for both mining companies and their stakeholders. It facilitates assessments and comparisons of company performance on a number of dimensions: notably profitability for investors, but potentially also their contribution to sustainable development. Companies report according to the demands of both formal legislation and regulations, and in some cases also according to voluntary standards. The most well-known and widespread of these is the Global Reporting Initiative (GRI). In some cases, voluntary standards have been made into legislation. One prominent example is

\footnotetext{
${ }_{7}$ Shooks, Malin et al. (2014). Safety and Health in European Mining: A report on safety and health, statistics, tools and laws, produced for the I2Mine (Innovative Technologies and Concepts for the Intelligent Deep Mine of the Future) project. Luleå: Luleå University of Technology; Elgstrand, Kaj \& Vingärd, Eva (eds.) (2013). Occupational Safety and Health in Mining: Anthology on the Situation in 16 Mining Countries. Gothenburg: University of Gothenburg.

${ }^{8}$ For a comparison of work environment legislation in Finland and Sweden, see e.g. Johansson, Bo \& Johansson, Jan (2008). Work environment and work organization in the Swedish and Finnish mining industry. Luleå: Luleå University of Technology.

${ }^{9}$ See Shooks et al. (2014) Safety and Health in European Mining: A report on safety and health, statistics, tools and laws, produced for the I2Mine (Innovative Technologies and Concepts for the Intelligent Deep Mine of the Future) project.

${ }^{10}$ Nordic Council of Ministers (2011). Comparative study of legislation and legal practices in the Nordic countries concerning labour inspection. Copenhagen: Nordic Council of Ministers.
} 
the EU adoption of the International Financial Reporting Standards, developed by the International Accounting Standards Board. A new Accounting Directive was adopted by the EU in 2013, to which member states have until 20 July 2015 to comply. Notably, special provisions apply for companies in the extractive industries, which shall report on payments to governments. Reporting requirements are comparable to what has to be disclosed by an undertaking participating in the Extractive Industries Transparency Initiative (EITI). ${ }^{11}$

Legislation on what information has to be disclosed varies depending on the size and type of company. On 29 September 2014, the European Council adopted the Directive on disclosure of non-financial and diversity information by large companies and groups. Companies concerned will have to disclose information on policies, risks and outcomes as regards environmental matters, social and employee-related aspects, respect for human rights, anti-corruption and bribery issues, and diversity on boards of directors. EU member states have two years to transpose the Directive into national legislation. The new rules apply to certain large companies with more than 500 employees, in total around 6,000 companies and groups across the EU, many of which already report voluntarily on sustainability. Most of the Nordic mining companies have fewer employees than this, and therefore the new reporting requirements should not be mandatory for them. However, the number of affected companies may increase in the process of national transposition, as member states have the right to go beyond the requirements of the EU directive. ${ }^{12}$

${ }_{11}$ EITI is a voluntary standard for disclosure of payments to governments. See more at https://eiti.org/

${ }^{12}$ See e.g. http://miljoaktuellt.idg.se/2.1845/1.604680/2-000-foretag-kan-fa-lamna-hallbarhetsrapport 


\section{Individual country mining and mineral legislation review}

\subsection{Denmark}

Denmark has no active mines, and lacks economically exploitable metallic mineral resources. ${ }^{13}$ Its extractive industry is focused mainly on nonmetallic minerals including salt, stone, gravel, sand, chalk and limestone, which are used primarily in building and construction projects in Denmark. Furthermore, the country has an offshore oil and gas sector. Production levels have been in decline since 2004. It generated DKK 22.1 bn in revenues to the Danish state in 2013, down from DKK 30.3 bn in 2011.

In addition to Denmark proper, the Kingdom of Denmark also comprises the autonomous countries of the Faroe Islands and Greenland. The latter has a history of mining, and a large potential for future exploitation. This will be covered in more detail in a separate chapter. Notably, Denmark ratified ILO convention 169, also known as the Indigenous and Tribal Peoples Convention, in 1996. The Danish Government has declared that the Inuit of Greenland are the only indigenous people in Denmark covered by the Convention, and that current home rule in Greenland is appropriate and in accordance with the provisions stipulated in its section $14 .{ }^{14}$

The Faroe Islands have had a degree of self-rule from Denmark since 1948. They are not considered to have any significant mineral resources, although a small amount of coal and industrial minerals is reportedly extracted for domestic consumption. There is also on-going offshore oil and gas exploration, but with no production as of yet. ${ }^{15}$

\footnotetext{
13 U.S. Geological Survey (2014). 2012 Minerals Yearbook. Denmark, the Faroe Islands, and Greenland. Reston, VA: USGS.

14 https://www.retsinformation.dk/Forms/R0710.aspx?id=85894

15 U.S. Geological Survey (2014). 2012 Minerals Yearbook. Denmark, the Faroe Islands, and Greenland.
} 
Unlike the Faroe Islands and Greenland, Denmark is a member of the EU. As a result, it is bound by a number of EU Directives, many of which are of relevance to the minerals industry.

\subsubsection{Permits and provisions according to the Subsoil Act}

The exploration and exploitation of Danish minerals is in principle governed through two laws: the Act on the Use of the Danish Subsoil of 2011, and the Raw Materials Act of 2013.16 The former covers those subsoil materials that were not subject to private commercial exploitation in Denmark prior to 23 February 1932, the year of a previous Subsoil Act. In practice, the Act covers natural gas, oil and salt, as well as production of geothermal energy and underground gas storage. The Act is applicable both on land and for the seabed within the Danish exclusive economic zone and continental shelf. The Ministry of Climate, Energy and Building is responsible authority for permitting according to the Act, but has delegated this to the Danish Energy Agency.

The Subsoil Act provides provisions for the granting of licences for preliminary investigations, exploration and production of raw materials. Similarly to mining laws in other Nordic countries, an exploration licence may give preferential right to a production licence. The Minister may lay down terms and conditions for the licence, including for payment of taxes and fees, and for reporting. Section 5-3 states that exploration and production licences "shall only be granted to applicants that are deemed to have the necessary expertise and financial resources, and who can be expected to carry on the activities in a manner so as to ensure that society gains maximum insight into and benefit from the activities". ${ }^{17}$ The same licences shall be submitted to a committee set up by the Danish Parliament for approval prior to granting.

Section 10 states that "exploration and production shall be carried on in a safe and appropriate manner that prevents any waste of raw materials". It furthermore requires licence holders to submit a work plan prior to beginning production, which shall be approved by the Ministry of Climate, Energy and Building. According to section 28a, an EIA is re-

\footnotetext{
${ }^{16}$ Author's translation. The Danish title of the law is "Bekendtgørelse af lov om råstoffer". No translated version of the document has been found on the Danish Government or authorities' websites.

17 This and following quotes from the Act on the Use of the Danish Subsoil is taken from a translated version of the document, which can be found on the Danish Energy Agency's official website: http://www.ens.dk/sites/ens.dk/files/undergrund-forsyning/olie-gas/koncessioner/guide-oliegaskoncessioner/GuideToHC.pdf
} 
quired for offshore projects that are assumed to have major impact on the environment. In this case, members of the public, authorities and organisations affected are to be given an opportunity to express their opinion. Furthermore, licences may only be granted if "the project does not adversely affect the integrity of an international nature protection area; or [...] weighty societal considerations, including of a social or economic nature, make it imperative to implement the project because no alternative solutions exist". The opinion of the European Commission is needed to grant permits in certain nature protection areas.

Other provisions in the Subsoil Act touch upon damage compensations, revocation of licences, expropriation of property, appeals processes and penalties, as well as special provisions for hydrocarbons, geothermal energy and underground storage.

Salt production is done at one location in Denmark. In 1963, the company Akzo Nobel Salt A/S was granted an exclusive right to produce salt from the Danish subsoil for fifty years. A licencing round was arranged prior to the termination of that period, but Akzo Nobel Salt A/S was the only company to express any interest. Subsequently, a new licence was granted in 2010, which this time only covers certain areas in Denmark. Total salt production was close to 580,000 tons in 2013 , employing around 150 persons. State revenue from royalties amounted to about DKK 6.2 M for the same year. ${ }^{18}$

\subsubsection{Permits and provisions according to the Raw Materials Act}

The Raw Materials Act of 2013 covers exploration for and exploitation of underground resources not covered by the Subsoil Act. Section 1 explicitly states that the Act covers stone, gravel, sand, clay, lime, chalk, peat, humus and similar material. The Act further differentiates between resources found on land and in the seabed. Like the Subsoil Act, the Raw Materials Act refers to the Minister of Environment as responsible authority, but much is delegated to the Danish Nature Agency.

The Act states that its objective is to secure that the exploitation of raw materials contributes to sustainable development through an as-

\footnotetext{
18 Danish Energy Agency (2014). Oil and Gas Production in Denmark 2013 and Subsoil Use. Copenhagen: Danish Energy Agency, 103; Danish Energy Agency (2010). Redegørelse efter $\S 6$ i undergrundsloven om en ny tilladelse til indvinding af salt ved opskylning til Akzo Nobel Salt A/S. Copenhagen: Danish Energy Agency, http://www.ft.dk/samling/20091/almdel/epu/bilag/186/810213/index.htm
} 
sessment and balancing of different interests. These include on the one hand the need for raw materials for commercial use, and on the other the protection of the environment, water supplies and cultural heritage, and considerations regarding urban development, infrastructure, agriculture, forestry, fishery and shipping.

The Regional Council is responsible for surveying raw materials and planning for their exploitation and supply. A number of provisions govern this process, such as the right of the Minister of Environment to instruct and veto plans, and the obligation to arrange public hearings. For commercial use, municipalities have had responsible for application processes and permission. However, from 1 July 2014, permitting responsibility has been taken over by the Regional Councils. ${ }^{19}$ Conditions are attached to the permit in order to limit environmental impact, including the provision of security for clean-up. Permit decisions may be appealed by the applicant as well as public authorities, affected individuals, and environmental and recreational associations.

For resources found in the seabed and continental shelf, the Minister of Environment is responsible for mapping and planning for raw materials. These belong to the Danish state. Exploration and exploitation permits are granted through an auction process. The Ministry stipulates a number of criteria which need to be fulfilled, such as a minimum programme of activities, after which the permit is granted to the highest bidder. An exploration permit holder may have priority to an exploitation permit. Like on land, an exploration permit for seabed resources comes with a number of conditions attached, including security for potential rehabilitation. An EIA may be needed prior to exploitation, whereby the public, authorities and private organisations are given opportunity to express their opinion. Similar appeals provisions as for land-based activities apply for seabed exploitation, with the exception that the latter identifies a larger number of relevant parties.

In 2013, the Nature Agency granted eleven new exploration permits following auction, and three new exploitation permits. In total, there are fifty current exploitation permits for exclusive rights to resources found in the seabed. Additionally, the Nature Agency may also designate cer-

\footnotetext{
${ }^{19}$ Earlier guidelines have been developed to help municipalities, see Danish Environment Agency (2011). Overblik over råstofindvinding - hvor og hvordan søges tilladelse. Copenhagen: Danish Environment Agency; and Danish Environment Agency (2007). Råstofinvdindning på land. Drejebog for VVM. Copenhagen: Danish Environment Agency. The Danish Raw Materials Assocation [Danske Råstoffer] had argued that municipalities in many cases lack adequate resources to handle permitting processes, an argument which has been similarly voiced in Norway. See http://www.danskeraastoffer.dk/nyheder/nyhedsvisning?docid=20522
} 
tain areas for common exploitation. In 2013, 88 such areas had been designated. A fee is paid based on the volume of material extracted. However, an exploiter may pay a lower fee if he or she carries the cost for exploration and environmental assessment of the area.

Finally, the Raw Materials Act contains a number of other provisions. These focus on expropriation of property, exploitation of raw materials for non-commercial use, monitoring, environmental damages, administration of the Act and penalties.

\subsubsection{Other legislation}

A number of other laws are of relevance for the Danish minerals industry. Some are referred to explicitly in the aforementioned Subsoil and Raw Materials acts. For example, section 5a of the latter states that the Regional Council's raw materials plan shall not violate provisions of the Planning Act and the Act on Environmental Objectives. The former together with the ordinances issued by the Ministry of Climate, Energy and Building include provisions on when and how EIAs are to be conducted. Like in other Nordic countries, this generally includes mining and minerals extraction, which presumably is a consequence of similar provisions in the EU EIA Directive.

Several other environmental laws are also of importance, such as the Act on Contaminated Soil, the Coastal Protection Act, and the Environmental Damage Act. With regards to safety, there is one law which more specifically targets activities governed under the Subsoil Act, but which like the latter is obviously focused on the offshore gas and oil industry rather than mining; namely, the Offshore Safety Act. The Taxation of Waste and Raw Materials Act will be revisited later on.

\subsection{Finland}

In 2013, there were 12 metallic mineral mines in operation in Finland together with 27 industrial mineral quarries which together employed circa 3,400 persons directly. The annual total turnover of the sector was around EUR $1.5 \mathrm{bn}$, of which metal mines accounted for two thirds. The Finnish mining sector is very much dominated by foreign-owned companies, unlike in Norway and Sweden. The country is considered the most attractive mining investment destination of all surveyed jurisdictions in an international survey conducted by the Fraser Institute in 2014. In 2010, the Finnish government adopted a national mining strat- 
egy with the aim to improve conditions and competitiveness of the sector. The strategy contained twelve action proposals focused on strengthening the country's minerals policy, securing the supply of raw materials, reducing the environmental impact of the minerals sector, increasing its productivity, and strengthening R\&D capabilities and expertise.

Since 2010, however, other challenges have become more apparent. These include securing labour supply to the minerals sector, facilitating investments, improving the processing of permit applications and, notably, handling conflicts of interest and improving dialogue between stakeholders. A number of roundtable discussions were therefore arranged between October 2012 and April 2013, which involved representatives from over 60 different parties such as non-governmental organisations (NGOs), companies and public agencies. This led to the development of a new action plan with 35 measures aimed at "[m]aking Finland a leader in the sustainable extractive industry". The Greenlandic, Norwegian and Swedish minerals strategies, adopted in 2014 and 2013, also reflect much of the shift in discussions on mining as is apparent in the new Finnish action plan.

Another important development in Finland is the adoption of a new Mining Act, which came into force on 1 July 2011 thereby replacing the previous Act from 1965. A new Government Decree on mining activities was issued one year later. The purpose of the revision was inter alia to enhance possibilities to include environmental and social considerations in the permitting process. ${ }^{20}$ It aims to reinforce the rights of landowners and residents of affected communities, inter alia through clarifying responsibilities of exploration and mining companies against other stakeholders; creating possibilities for landowners, local organisations and citizens to submit their opinions during the permitting process, before decisions are taken; and to a larger extent taking into account the views of local municipalities and environment authorities about projects. ${ }^{21}$

\footnotetext{
20 See Government of Finland (2009). Regeringens proposition till Riksdagen med förslag till gruvlag och vissa lagar som har samband med den, RP 273/2009 rd. Helsinki: Government of Finland; Pettersson et al. (2015). License to Mine: a comparison of the scope of the environmental assessment in Sweden, Finland and Russia. Natural Resources 6.4, 237-255.

${ }^{21}$ See Williams, John P. (2012). Global trends and tribulations in mining regulation. Journal of Energy \& Natural Resources Law 30; Ministry of Employment and the Economy (2011). New Mining Act to enter into force on 1 July. Helsinki: Ministry of Employment and the Economy, https://www.tem.fi/en/current_issues/

press_releases/press_release_archive/year_2011/new_mining_act_to_enter_into_force_on_1_july.103119.news
} 
It is difficult to evaluate the effects of the new Mining Act as there are relatively few cases that have been tried under it so far. Cases submitted before its adoption have been tried under the former act, of which there was a considerable backlog. The exploitation of certain materials, such as stone, gravel, sand and clay, is governed under the Soil Resources Act of 1981. This will not be covered here.

\subsubsection{Permits according to the Mining Act}

The first chapter of the Finnish Mining Act sets out general provisions including the purpose of the act. It states that the objective of the act is "to promote mining and organise the use of areas required for it, and exploration, in a socially, economically, and ecologically sustainable manner". ${ }^{22} \mathrm{~A}$ similar provision can be found in the Norwegian Minerals Act.

The Act applies to the exploration and exploitation of so-called "mining minerals". The Act specifies which chemical elements and minerals that are considered as mining elements, which includes metallic minerals but excludes industrial minerals such as gravel and sand. Exploitation of the latter is regulated through the Land Extraction Act. What is considered to be mining minerals in Finland very much corresponds to what is denominated as state minerals in Norway and concession minerals in Sweden. Unlike the Norwegian and Swedish mineral acts, the Finnish Mining Act regulates gold panning on state-owned land through specific provisions.

In Finland, everyone has a right to conduct limited prospecting work such as making observations and taking small samples, even on land belonging to somebody else. Certain limitations exist, and notification including a plan regarding sampling must be sent to the landowner. A permit is needed in cases of more extensive exploration that may cause harm to human health, to public safety or to other forms of livelihood, or may weaken scenic or nature conservation values. This includes all cases of uranium exploration. A permit may also be needed in case the landowner does not consent to prospecting, and only an issued permit assures the exclusive rights to exploration in the area. Permits are issued by the Finnish Safety and Chemicals Agency (Tukes).

22 This and following quotes from the Mining Act are taken from a translated version of the document, which can be found on the Finnish Ministry of Justice' online database: http://www.finlex.fi/sv/laki/kaannokset/ 2011/en20110621.pdf 
Prior to applying for an exploration permit, an applicant may reserve an area through notification to the authority. An exploration permit also gives priority to an exploitation permit later on. Depending on the type of exploration activity, the permit holder may have to guarantee security for covering any damage caused or rehabilitation. Here as well, notifications shall be sent to landowners, but also to other holders of rights. This may include e.g. reindeer herders, which we will revisit shortly. Section 34 of the Mining Act lists what shall be included in an application, such as information on the area and who's interests, rights and duties may be affected; a preliminary assessment of the mining minerals in the area; a work plan; an assessment of environmental and other impacts of activities; and a waste management plan and information on after-care measures.

For the establishment of a mine, a mining permit is necessary. Tukes is licensing authority, except in the cases of uranium and thorium, where the Government decides whether or not to grant a permit.23 The application is to contain the same information as for the exploration permit, but additionally, a more extensive assessment of the suitability of the deposit for exploitation is needed. Also, an EIA according to the Act on Environmental Impact Assessment Procedure is needed. EIA regulations will be revisited later. Like for exploration and gold panning permit applications, Tukes shall request a statement on the activity from the relevant municipality; the Centre of Economic Development, Transport and the Environment in the region; ${ }^{24}$ the authority or institution responsible for management of the area, and; if necessary, other authorities, the Regional Council or other parties in view of permit considerations. A hearing shall be arranged where the applicant and other parties are provided with an opportunity to express their opinions and provide explanations.

In order for a mining permit to be granted, the deposit needs to be exploitable in terms of size, ore content and technical characteristics. Also, according to section 48 , "a permit shall not be granted if the mining activity causes danger to public safety, causes highly significant detrimental environmental impacts, or substantially weakens the living conditions and industrial conditions of the locality, and the said danger or

\footnotetext{
${ }^{23}$ Kokko, Kai et al. (2014). Sound mining in the North: a guide to environmental regulation and best practices supporting social sustainability, 31-32.

${ }^{24}$ A public authority responsible for the regional implementation and development tasks of the central government in areas of business and industry, labour force, competence and cultural activities, transport and infrastructure, and environment and natural resources.
} 
impacts cannot be remedied through permit regulations". Hence, a number of conditions are attached to the mining permit, such as measures to protect health, safety and the environment, as well as requirements regarding security for after-care.

Access to the land needed for mining activity should be arranged by voluntary arrangements. If that is not achieved, a redemption permit can be granted by the Government if the mining project is of importance based on public need. Such a permit allows the mining operation to obtain ownership or usufruct rights to the area needed. According to section 49, "[t]he requirement of public need shall be assessed particularly on the basis of the impact of the mining project on the local and regional economy and employment, and the social need for raw material supply". Prior to granting a redemption permit, the Government must request a statement from the relevant municipality, Regional Council, and the Centre of Economic Development, Transport and the Environment.

As mentioned earlier, gold panning permits are regulated through the Finnish Mining Act. This applies to areas owned by the state. Legal effects are similar to those of a mining permit. In other words, it gives exclusive rights to exploit minerals, more specifically gold and certain other gemstones, but also includes obligations regarding safety, reporting, after-care measures and related security.

The Mining Act presents provisions for an additional permit: the Mining safety permit. General details on mining safety requirements are presented in chapter 11 , chapter 12 focuses on regulations pertaining to the safety permitting process, chapter 13 on mining machinery and equipment and chapter 14 on inspection bodies. For example, mining operators are to "systematically determine and identify elements endangering mining safety" and prepare a rescue plan. ${ }^{25}$ After a permit application has been submitted, Tukes requests statements from other competent authorities such as the local rescue authority, and the Radiation and Nuclear Safety Authority. Here as well, parties involved are allowed to lodge a complaint and other parties are provided with an opportunity to express their opinion, and the permit decision must comment on these statements. Mining operators must inform Tukes of any serious accidents, dangerous situations or incidents. In turn, Tukes is obliged to investigate accidents if necessary to determine their reason or to prevent similar happenings in the future.

${ }^{25}$ Section 114. 


\subsubsection{Provisions regarding Samis, Skolts and reindeer herding}

Unlike the Swedish Minerals Act, the Finnish Mining Act explicitly refers to the aim of securing the rights of the Sami as an indigenous people. The Finnish Sami population is commonly considered to number around 8,000 persons, which is smaller than in Norway and Sweden. Of this population, just below $40 \%$ live in the "Sami homeland", also known as the Sami native region. The country's constitution defines this region as consisting of the municipalities of Enontekiö, Utsjoki and Inari as well as a part of the municipality of Sodankylä. The state is the legal owner of $90 \%$ of the land designated as Sami homeland. Notably, Samis do not exercise exclusive rights to reindeer herding outside of the designated native region, unlike in Norway and Sweden. Thus, the Sami native area does not correspond to the reindeer herding area, which covers most of the region of Lapland as well as northern parts of the region of North Ostrobothnia. In addition, Finland is also home to the Skolt people, which is a distinct Sami group. A separate law, the Skolt Act of 1995, includes provisions on their rights of in the Skolt native area, which forms a part of the Sami native area in Inari municipality.

The Finnish Mining Act includes several provisions for mining activities to be conducted in Sami and Skolt native areas or reindeer herding areas. This differs from Sweden where it is Sami reindeer herding rights that have a degree of legal protection, which in turn is not explicitly mentioned in the Minerals Act but rather through related legislation. The first section of the Finnish Mining Act states that activities referred to shall be adapted in the Sami homeland "so as to secure the rights of the Sami as an indigenous people. This adaptation shall pay due attention to the provisions of the Skolt Act (kolttalaki 253/1995) concerning the promotion of the living conditions of the Skolt population and Skolt area, opportunities for making a living, and the preservation and promotion of the Skolt culture". 26

Section 38 of the Mining Act specifies the procedure to be applied in the case of exploration, gold panning or mining permit applications in the Sami Homeland, Skolt area and special reindeer herding areas. In the first case, Tukes as permit authority is obliged to establish potential impact of activities on the Samis' rights to maintain and develop their own language and culture prior to approving any permits. This involves

${ }^{26}$ Section 1. 
cooperating with stakeholders such as the Sami Parliament, local reindeer owners' association and competent local administration. This may also apply for areas outside the Homeland of considerable significance as regards the rights of the Samis as an indigenous people. In the Skolt area, Tukes shall request a statement from a Skolt village meeting concerning assessments of the impacts of planned activities in their sources of livelihood and living conditions. And in a special reindeer herding areas, Tukes shall in cooperation with the local reindeer owners' association assess potential damage. The Mining Act lists a number of stakeholders which Tukes may invite to a consultation meeting with the applicant in order to clarify matters.

Section 50 of the Mining Act states that, in cases of permit applications in the Sami Homeland, Skolt area and special reindeer herding areas, a permit shall not be granted if it undermines conditions for Sami or Skolt livelihood and culture, or considerably harms reindeer herding. The Act states that the permit authority shall take into consideration not just the potential effect of the permit applied for, but also of any other corresponding permits or other activities, such as forestry, in the area. ${ }^{27}$ In other words, in those areas, the cumulative effect of permits shall be kept in mind. And furthermore, if relevant, the Sami Parliament, Skolt village meeting or local reindeer owners' association are to participate in the final inspection following mine-closure measures, according to section 146(2).

Again, since so few cases have been tried under the new Mining Act, it is difficult to establish how strongly it protects the rights and interests of Samis, Skolts and reindeer herders in practice. In theory though, it looks strong. ${ }^{28}$ In a proposition to the Finnish Parliament, the Government writes that it does not wish to change the current rights of Samis vis-à-vis non-Samis to land ownership or economic activities, but rather to develop the rights of Samis to influence planning and decision-making on the management of state-owned land and water in their native area. ${ }^{29}$

\footnotetext{
${ }^{27}$ See both section 38 and section 50 .

${ }^{28}$ See Koivurova, Timo \& Petrétei, Anna (2014). Enacting a New Mining Act in Finland - How were Sami

Rights and Interests Taken into Account? Nordic Environmental Law Journal 1, 126-127.

${ }^{29}$ See http://oikeusministerio.fi/sv/index/aktuellt/tiedotteet/2014/11/ilo-

sopimuksenratifiointiesityseduskunnalle_0.html
} 
Currently, there are no mines in the Sami native region, but there is gold panning. Since the adoption of the new Mining Act, 99\% of gold panning applications are for this region, but no exploration permits or mining permits. While the Sami parliament does not oppose traditional gold panning, they have expressed opposition to mechanised gold panning projects. The number of gold panning claims currently in force is approximately 260 . The highest number of gold panning claims is found in the municipality of Inari, in the area of the river Ivalojoki and its tributaries. Claims can also be found in the Lemmenjoki National Park and in the municipalities of Sodankylä and Salla. However, mining rights according to the old Mining Act, under which gold panning is currently done, will expire in 2020. Thereafter, gold panning will have to be done according to provisions of the new Act, which notably means that mechanised gold panning will be prohibited in Lemmenjoki National Park.

\subsubsection{Other provisions in the Mining Act}

Chapter 8 of the Mining Act lays out provisions on the proceedings of establishing a mining area, which also includes related compensations. More provisions on compensations are however presented in chapter 9. This includes compensations to landowners for mineral exploration and extraction, and to authorities and institutions for gold panning in areas under their management. Compensation rates are presented in appendix A. Further, chapter 10 of the Act focuses on collateral for mining activities, which type and quantity is to be determined by Tukes as mining authority.

The Act also contains a number of provisions around the possibility to appeal decisions made by Tukes or by the Government. According to section 165 , decisions on exploration, mining and gold panning permits may be appealed by, inter alia, the party concerned; a registered association or foundation which operates in the relevant area and whose purpose is to promote protection of the environment or health; the relevant municipality; a Centre for Economic Development, Transport and the Environment; the Sami Parliament, on the grounds that the activity referred to in the permit undermines the rights of the Sami as an indigenous people to maintain and develop their own language and culture; and the Skolt village meeting, on the grounds that the activity referred to in the permit impairs the living conditions of the Skolt population in the Skolt area and the possibilities for making a living there.

Finally, the Mining Act describes the process around termination of mining activities and subsequent clean-up, after which notification shall be sent to Tukes which arranges a final inspection. Like with permitting, 
a number of other stakeholders are to be informed about the inspection and allowed to express their opinion on the matter. There are also provisions regarding supervision and monitoring both during and after mining, as well as administrative regulations around the enforcement of the Act itself.

\subsubsection{Other legislation and permits}

In addition to the permits specified in the Mining Act, a number of other permits according to other laws are also necessary in order to open a mine. These permitting procedures often involve a hearing process where parties concerned including the public as well as local, regional and national authorities are included. Notably, the developer needs an environmental permit in compliance with the Environmental Protection Act, which is issued by the Regional State Administrative Agency. An environmental permit here can be understood as an emissions permit, and it does not relate to the question of use and ownership of the area. ${ }^{30}$ Supervision of compliance to conditions in the environmental permit is conducted by the Centres for Economic Development, Transport and the Environment.

EIAs are regulated in a separate Finnish law, as compared to Sweden where this falls under the Environmental Code, and Denmark and Norway where this is mainly regulated through planning and building laws and subsequent ordinances. Main responsible authority for the EIA in Finland is the Centres for Economic Development, Transport and the Environment. The first step of the process is the submission of an assessment programme by the project developer. After this, a hearing is arranged during which a number of stakeholders are involved. The developer then performs required investigations and submits a report to the responsible authority. Outcome from the EIA informs both the mining permit and environmental permit application process. Notably, the double hearing EIA process differs from its Swedish counterpart, where it is usually limited to one instance. And furthermore, the content requirements seem to be more extensive in the Finnish case. ${ }^{31}$

\footnotetext{
${ }^{30}$ Kauppila, Päivi, Räisänen, Marja Liisa \& Myllyoja, Sari (2011). Best environmental Practices in Metal Ore Mining. Helsinki: Finnish Environment Institute, 51.

31 Pettersson et al. (2015). License to Mine: a comparison of the scope of the environmental assessment in Sweden, Finland and Russia.
} 
Other permits needed include: a water resource management permit, in accordance with the Water Act, also issues by the Regional State Administrative Agency; and building permits, from the municipality. The land use planning process is also of importance. An exploration or gold panning permit may not be granted for an area where such activities would impede the implementation of a legally binding plan. Finally, the Finnish Government has also issued ordinances that specifically focus on mine safety. This includes ordinances on mine safety and on hoist equipment, pursuant of the Mining Act.

Mote detailed information on environmental regulation, EIA procedures, Natura 2000-assessments and land use planning processes can be found in the publication "Sound Mining in the North. A guide to Environmental Regulation and Best Practices Supporting Social Sustainability". ${ }^{32}$ More recently, the Ministry of Employment and the Economy has published a guide on exploration in protected areas, the Sami homeland and reindeer herding areas. ${ }^{33}$ Another albeit dated publication which includes a review of environmental legislation is "Best Environmental Practices in Metal Ore Mining", published by the Finnish Environmental Institute in 2001.34

Other laws of importance for mining activities include the Nature Conservation Act and the Act of Protection of Wilderness Reserves, as well as the Land Use and Building Act, the Occupational Safety and Health Act and legislation related to the Sami Parliament and reindeer herding. In addition there are a number of relevant Government decrees.

\subsubsection{Other notes}

In comparison to Sweden, the Finnish Mining Act is more detailed than its Norwegian and Swedish counterparts. As a crude illustration, it includes 188 sections compared to 139 in the Sweden and 70 in Norway. Compared to Sweden, the permitting process includes more instances of mandatory public hearings. Hearings and consultations should ideally also serve as a tool for solving conflicts. However, there is also risk of processes becoming very slow and cumbersome, especially if it is not

\footnotetext{
32 Kokko et al. (2014). Sound mining in the North: a guide to environmental regulation and best practices supporting social sustainability.

33 Ministry of Employment and the Economy (2014). Guide. Exploration in protected areas, the Sámi homeland and the reindeer managing area. Helsinki: Ministry of Employment and the Economy.

${ }^{34}$ Kauppila et al. (2011). Best environmental Practices in Metal Ore Mining.
} 
possible to limit the number of parties involved. Again though, there is yet too little experience from cases tried under the new Mining Act to draw any general conclusions.

Unlike in Greenland but like in other Nordic countries, SIAs are not mandatory by law. However, they are reportedly more common in Finnish mining projects than in Swedish ones. One reason for this may be that the Finnish mining sector is very much internationalised, and that foreign investors and companies have brought with them approaches more common in countries such as Canada.

With regards to voluntary initiatives and regulations, the Finnish Mining Association, FinnMin, has not adopted any ethical guidelines for its members, like its Norwegian and Swedish counterparts. On the other hand, there is an on-going initiative led by the organisation Sitra which is focused on promoting sustainable practices within the mining industry. This will be presented in more detail later on in this report.

Finally, Åland is an autonomous region of Finland and, like the Faroe Islands and Greenland, an independent member of the Nordic Council. There are no active mines of Åland and no known deposits that may be feasibly exploited within the near future.

\subsection{Greenland}

Greenland is, like the Faroe Islands, an autonomous country in the Kingdom of Denmark. It has had "home rule" since 1979 and "self-rule" since 2009. Denmark ratified ILO convention 169 in 1996, and the Danish Government considers the current self-rule regime in Greenland to be in accordance with its international obligations. ${ }^{35}$ Consequently, the Greenlandic government has authority over natural resource development. However, with regards to uranium, there has been a discussion on the competence of the Government of Greenland due to foreign, defence and security policy considerations, which in turn is still governed by its Danish counterpart. ${ }^{36}$ Furthermore, Greenland left the European Communities following a referendum in 1985 , but retains a special relationship.

\footnotetext{
35 https://www.retsinformation.dk/Forms/R0710.aspx?id=85894

${ }^{36} \mathrm{http}: / /$ www.mining.com/denmark-to-decide-whether-greenland-can-start-mining-uranium-14660/
} 
Greenland differs from the other Nordic countries in notable ways. It is geographically much more isolated, and had a population of only 55,984 as of 1 January 2015 . Of these, around $85 \%$ are indigenous Inuits, and one in four of the inhabitants live in the capital Nuuk. Greenland suffers from net migration, and the level of education attainment is low compared to other Nordic countries. Consequently, high cost of transportation and a lack of skilled local workers is a notable obstacle to mining. Harsh climate is another and related obstacle, although accessibility is expected to improve with global warming.

Mining has the potential to play a relatively much more important role for the Greenlandic economy than in other Nordic countries. Today, the country is very much dependent on an annual block grant from the Danish government. Seafood makes up 90\% of Greenland's exports. ${ }^{37}$ However, there are currently no active mines in Greenland, although there have been in the past. A number of proposed mining projects exist, in various phases of realisation. A ruby mine is expected to open in 2015, and an anorthosite quarry in 2016. Rare earth element and uranium projects are some years into the future. The mineral potential of Greenland is big, and the Greenland Government has actively promoted the development of a mining industry.

Like Finland, Norway and Sweden, the Greenland Government has adopted a mineral strategy. The current strategy succeeds earlier strategies, and covers the period of 2014-2018. The aim of the Government is that there should always be five to ten active mines in Greenland in the long term, which they estimate may provide tax revenues of DKK 30 bn over the next 15 years. In the short run, the strategy states that they expect three to five mines to be established within five years from writing. The Government focuses in particular on iron ore, copper, zinc, rare earth elements, gold and gemstones. All in all, the strategy presents 19 strategic priorities with respect to minerals, and 43 strategic priorities related to sustainable development. Several of the latter are focused on the minerals industry, and cover environmental protection, business community, financing of infrastructure facilities, energy supply, airports, harbour capacity, telecommunications, labour market and employment, training, health and social sector, stakeholders, and sustainable social benefits. ${ }^{38}$

\footnotetext{
37 http://www.ft.dk/samling/20131/almdel/gru/bilag/66/1389730.pdf

38 Government of Greenland (2014). Greenland's oil and mineral strategy 2014-2018. Nuuk: Government of Greenland.
} 
A new act on mineral resources came into force on 1 January 2010, replacing the older Danish act. The Mineral Resource Act was later subject to revision in 2012, when inter alia supervisory and approval tasks were separated from strategic planning and marketing, and in 2014, when provisions regarding pre-consultations and consultations were added. The Act covers minerals as well as hydrocarbons and subsoil storage, e.g. of greenhouse gases. Notably, it does not differentiate between various minerals as do mineral laws in other Nordic countries, where in the latter case certain minerals are recognised as belonging to the property-owner. In addition to prospecting, exploration, exploitation and export, the Act also covers activities done in relation to this, such as the development of energy supplies and the establishment and operation of pipelines. Licences for the latter activities may be granted as a part of an exploitation licence, which we will look at now.

\subsubsection{Permits according to the Mineral Resources Act}

Section 1-2 of the Mineral Resources Act states that " $[\mathrm{t}]$ he Greenland Parliament Act aims to ensure that activities under the Act are securely performed as regards safety, health, the environment, resource exploitation and social sustainability as well as properly performed according to acknowledged best international practices under similar conditions". 39 The Mineral Licence and Safety Authority is overall administrative authority, ${ }^{40}$ except for environmental matters, for which the Environmental Protection Agency for Mineral Resource Activities is responsible. Appeals regarding decisions made by the two authorities can be submitted to the Greenland Government. Those entitled to appeal are parties to the case, those who have a major individual interest in the outcome of the case, as well as recreational and environmental associations.

The Mineral Resources Act allows for the granting of the following licences: prospecting licence, exploration licence and exploitation licence. Prospecting licences may be granted for up to five years at a time. It does

\footnotetext{
39 This and following quotes from the Mineral Resources Act are taken from a translated version of the document, which can be found on the Greenland Government's official website: http://www.govmin.gl/images/stories/ about_bmp/Unofficiel_translation_-_Mineral_Resources_Act_as_amended_by_act_no_6_of_june_8_2014_-_pdf.pdf 40 Until 1 January 2013, the Bureau of Minerals and Petroleum was responsible for mineral licencing, monitoring, environmental administration, marketing, and taking initiatives around legislation. These responsibilities are today shared by the new Mineral Licence and Safety Authority, the Environment Agency for Mineral Resource Activities, and the Ministry for Industry and Minerals.
} 
not necessarily give exclusive right to prospecting in an area. Conditions may be attached to the licence.

Exploration and exploitation licences may be granted together in the case of hydrocarbons, and separately in the case of minerals. A mineral exploration licence holder who has discovered and delimited commercially exploitable deposits is entitled to be granted an exploitation licence. Exploration and exploitation licences shall include information on the amount to be paid in fees and royalties to the Greenland Self-Government. Following sections 17 and 30, an exploitation licence succeeding an exploration licence generally includes the same terms regarding payments to government as found in the former. Additionally, licences shall include information on the extent to which the licence holder must enter into and comply with an agreement on social sustainability and other socioeconomic issues. More specifically, section 18 states that a licence must include information on the extent to which the licence holder has to use labour from Greenland and use Greenland enterprises for contracts, supplies and services. Also, the licence may (as opposed to "shall") include information on the extent to which the licence holder must process exploited mineral resources in Greenland; must keep exploited mineral resources in Greenland and sell them to natural persons who are permanently residing and fully liable to pay tax in Greenland, and; must conduct surveys and prepare and implement plans to ensure that exploration or exploitation of mineral resources is socially sustainable, which must be approved by the Greenland Government.

Prior to commencing exploitation activities, exploitation plans including production organisation and related facilities must be approved by the Greenland Government. Specific work commitments may be included in the exploitation licence. A closure plan must also be prepared and approved. This shall include information on how the mining site will be left after cessation of activities, the potential requirement for continued maintenance and monitoring activities, and how this shall be financed, i.e. which security will be provided.

The Mineral Resources Act allows for the granting of small-scale exploration and exploitation licences. These can only be granted to natural persons who fulfil certain criteria regarding residency in Greenland, as well as to museums. The general rights following a small-scale licence are similar to those for a normal licence. For example, they can be both exclusive and nonexclusive, and holders of exploration licences may have a preferential right to an exploitation licence. Licences are limited both in size and time. An exclusive small-scale licence cannot be larger than 1 square kilometre, and 
is granted for a period up to three years, which may be extended if a commercially exploitable deposit has been demonstrated.

Small-scale licences shall stipulate provisions on activities to be performed; namely, which activities may be done without special approval, which may only be conducted with an approval, and which activities may not be done at all. For example, only handheld non-mechanical tools may be used under a non-exclusive small-scale licence, without an additional licence. Small-scale licence applications are exempted from obligations to conduct surveys and plans for social sustainability, or an EIA. On the other hand, exploitation licence holders usually need to prepare and gain approval for an exploitation plan as well as a closure plan prior to beginning activities.

Finally, according to part 11 of the Mineral Resources Act, a person who is a permanent residence of, and fully liable to pay tax in, Greenland, may carry out non-commercial collection of loose minerals without a licence. The maximum value of minerals collected according to this provision is DKK 100,000 per year. If a person has collected minerals under this right, a small-scale exploitation licence is needed in order to sell or process them. For certain minerals, a licence is always needed for collection and extraction, such as for diamonds and radioactive material. Also, the Greenland Government may approve that local authorities or concrete-manufacturers collect and extract gravel, stone and similar minerals to be used locally. If an exploitation approval is granted, a licence is not needed. Terms of exploitation may be attached to an approval, for example to protect safety, health and the environment.

\subsubsection{Other provisions in the Mineral Resources Act}

The Mineral Resources Act includes a relatively large number of provisions beyond the administration of rights following licences. For example, they cover environmental protection, climate protection and nature conservation. Their aim is "to help protect the climate so that society can develop on a sustainable basis respecting human conditions of life and respecting preservation of animal and plant life". Inter alia, the Act presents principles according to which mineral activities shall be conducted, such as the application of best available technique, and provisions on the liability for environmental damage.

Except for the above-mentioned small-scale licences, an EIA and a social impact assessment (SIA) need to be conducted by the exploitation licence holder, and approved by the Greenland Government, in order to commence mining. According to section 77-1, the SIA "report must ap- 
propriately demonstrate, describe and assess the direct and indirect impacts of the activity on social conditions as well as the interaction between the conditions, mutual impact between the conditions and cumulative effects of impacts on the conditions". The Bureau of Minerals and Petroleum has published guidelines both for how EIAs and SIAs should be prepared. Accordingly, SIAs should cover aspects such as "business and employment, income and other socio-economic aspects, use of land and resources, health, education, infrastructure and sociocultural features". ${ }^{41}$

The first step in both the EIA and SIA process involves the preparation and submission of a project description by the licence holder, which is followed by a public pre-consultation period. After that, the content of the assessments is determined. Section $95 a-1$ of the Act stipulates that a fund shall be established by the Government, "from which affected citizens, local communities and relevant organisations in Greenland can apply for funding to initiate assessments and seek advice to identify any special problems in relation to specific mineral resource projects in Greenland as well as to hold meetings about the social and environmental impact of the project [...] Applications for funding may be made after a project description has gone out for pre-consultation". Another public consultation is arranged after the EIA and SIA reports have been submitted. The Greenland Government is responsible for conducting town and village meetings, and for deciding on where these shall be arranged. It may also decide that more material is needed for the conclusion of the assessment, before approval can be given.

Other issues also covered by the Mineral Resources Act include compulsory acquisition of real property, export and import of minerals, reporting, sanctions, and administrative provisions regarding the implementation of the Act itself. Also, the Act contains a number of provisions that are specific for oil and gas exploitation, such as offshore safety rules, and for subsoil storage.

\subsubsection{Other legislation and permits}

Beyond the Mineral Resources Act, the Danish Act on Greenland SelfGovernment of 2011 is of obvious importance. Section 7 of the Self-

\footnotetext{
${ }^{41}$ Bureau of Minerals and Petroleum (2009). Guidelines for Social Impact Assessments for mining projects in Greenland. Bureau of Minerals and Petroleum, 3.
} 
Government Act states that "[r]evenue from mineral resource activities in Greenland shall accrue to the Greenland Self-Government authorities". Furthermore, section 8-1 states that "[i]f revenue from mineral resource activities in Greenland accrues to the Greenland Self-Government authorities, [...] the Government's subsidy to the Self-Government authorities shall be reduced by an amount corresponding to half the revenue which, in the year concerned, exceeds DKK 75 million [to be adjusted annually]". Several other acts are also of importance for mineral activities in Greenland. Notably though, the Environment Protection Act of 2011 states that it does not cover activities governed under the Mineral Resources Act.

In 2012, the Greenland Parliament passed the Large Scale Project Act which allows, subject to approval from the Greenland Government, companies to use international tender and foreign workforce on international terms for the construction of new mines. The Act applies to projects with capital expenditures exceeding DKK 5 bn, where labour demand is deemed beyond what can be supplied of suitable and available workforce in Greenland, or where local companies lack necessary technical or economic capacity. The Act does not cover relatively unqualified work tasks associated to construction work, such as cleaning, canteen management, local transportation et cetera. An EIA and SIA have to be submitted in order for the Government to approve of a company's application of the provisions of the Large Scale Project Act, based on which an Impact Benefit Agreement shall be developed. Furthermore, the Act includes a number of more detailed provisions regarding the rights of workers, e.g. with regards to wages, union membership, accommodation and holidays. As Greenland has not been devolved competence over migration policy, the Danish Parliament had to adopt a new Act in order for the Large Scale Project Act to come into force. This was done on 11 June 2014.

On the basis of an SIA, the Government, company and other public agencies, such as the local municipality, shall negotiate an Impact Benefit Agreement. According to the aforementioned guidelines from the $\mathrm{Bu}-$ reau of Minerals and Petroleum, the Impact Benefit Agreement "defines the cooperation between the licensee, national authorities and local authorities in relation to maximizing development opportunities and mitigating impacts from mining projects. At least three months should be available for concentrated IBA negotiations. The IBA shall as a main rule be signed at the same time as the exploitation licence is granted, and the [Benefit and Impact Plan, Monitoring Plan and Evaluation Plan] shall be 
adjusted to meet the targets of the IBA within 60 days from signing the agreement". ${ }^{42}$

Greenland has significant deposits of rare earth minerals as well as uranium. On 24 October 2013, the Parliament of Greenland voted to uplift an earlier moratorium on uranium extraction. ${ }^{43}$ Prior to the decision, a working group composed of members from the Danish and Greenland governments had published a report which identified a number of potential legal and political consequences of such a decision. Notably, while the Government of Greenland has control of mineral policy, the Danish Government still retains control over foreign and defence policy, and arguably uranium has important implications for both policy areas. The report concluded that the Governments of Greenland and Denmark disagree on competence surrounding uranium, but that they agree to seek practical cooperation. ${ }^{44}$ However, there is also disagreement between the Government of Greenland and that of Denmark on the control of production and export of other rare earth minerals. These issues are still being discussed at the time of writing.

\subsubsection{Other notes}

As noted, mineral exploitation may potentially play an important role in the development of Greenland. In 2008, a law was passed according to which a fund shall be established after natural resource income exceeds DKK $5 \mathrm{M}$ per year. A fund does not seem to have been established at the time of writing. The Greenland Government has proposed increasing that benchmark sum to DKK $75 \mathrm{M}$ per year, but this has not yet been passed by the Parliament.

Several initiatives have looked more closely at the governance of both mineral exploitation and ensuing profits. One notable example is the Committee for Greenlandic Mineral Resources to the Benefit of Society, which was established in early 2013 by the University of Copenhagen together with the University of Greenland. The committee was tasked to consider existing information and research in order to provide an overall

\footnotetext{
42 Bureau of Minerals and Petroleum (2009). Guidelines for Social Impact Assessments for mining projects in Greenland. 13.

${ }^{43}$ According to the "zero-tolerance policy", one tonne of extracted ore could contain a maximum of 60 grams of uranium.

${ }^{44}$ Arbejdsgruppen om konsekvenserne af ophævelse af nul-tolerancepolitikken (2013). Rapport om udvinding og eksport af uran. The report can be downloaded in Danish and Greenlandic here: http://gme.gl/rapport-omudvinding-og-eksport-af-uran
} 
view of the challenges related to mineral development, and how it can contribute to Greenlandic society. They published their report and recommendations a year later. ${ }^{45}$ Another example is an initiative run by WWF and the Inuit Circumpolar Council, which has also resulted in the publication of a number of reports on mining in Greenland. 46

\subsection{Iceland}

Compared to its Fennoscandian neighbours, Iceland has a relatively small minerals industry. From November 2013 to October 2014, companies in the mining and quarrying sector had a turnover of ISK 4,381 bn (ca. EUR $30 \mathrm{M}$ ). ${ }^{47}$ The country has few proven mineral resources. ${ }^{48}$ Some extraction of industrial minerals exists, notably pumice which is exported abroad. Iceland has no metallic mines today. However, there is on-going exploration in different parts of Iceland for gold. According to one explorer, results have shown that the grade of gold in certain areas is high enough for production, but they have yet to determine if the quantity is sufficient. ${ }^{49}$ Due to the abundance of geothermal energy, Iceland has specialised on aluminium smelting based on imported material. Oil and gas exploration licences were issued in early 2012, but no exploitable discoveries have been made as of yet.

Iceland is not a member of the EU, but is closely associated through membership of the European Free Trade Association (EFTA) and thereby the European Economic Area (EEA). As a result, Iceland follows much of EU legislation related to the single market. Environmental legislation is one area in which harmonisation has been notable. ${ }^{50}$ Iceland applied to join the EU in 2009 and formal negotiations began a year later. However, in 2013 the Government of Iceland announced that it had decided to suspend the EU accession negotiations.

\footnotetext{
45 Committee for Greenlandic Mineral Resources to the Benefit of Society (2014). For the benefit of Greenland. Nuuk: University of Greenland. See more information on project here: http://news.ku.dk/greenland-naturalresources/

${ }^{46} \mathrm{http}$ ://inuit.org/en/activities/reports/icc-and-wwf-reports-on-mining-activities-in-greenland.html

$47 \mathrm{http}: / /$ www.statice.is/Pages/444?NewsID=11082

48 U.S. Geological Survey (2014). 2012 Minerals Yearbook. Iceland. Reston, VA: USGS.

49 http://grapevine.is/news/2014/09/03/foreign-investors-join-icelandic-gold-rush/

${ }^{50} \mathrm{http}: / /$ ec.europa.eu/enlargement/pdf/iceland/key-documents/screening_report_27_is_internet_en.pdf
} 
The Act on the Survey and Utilisation of Ground Resources of 1998 covers mineral prospecting and exploitation. It applies to resources found in the ground, but also the bottom of rivers, lakes and the sea up to 115 metres from the shore and 115 metres below the low water line of a property. Minerals are defined as "all volcanic substances and other mineral substances, metals, metal blends and metallic rock, coal, petroleum, natural gas and other extractable substances that may be found in the ground". ${ }^{51}$ For obvious reasons though, the Act focuses more on geothermal energy. The National Energy Authority is main responsible authority for licencing according to the Act.

\subsubsection{Permits according to Act on the Survey and Utilisation of Ground Resources}

According to section 3 of the Act, minerals belong to the property owner. Conversely, the state owns those minerals that are found on publicly owned lands. If prospecting or exploration is carried out by the landowner, 52 a licence is not needed from the National Energy Authority. However, the landowner is required to send a work plan to the Authority, which may in turn impose conditions on activities as necessary for safety or technical reasons, or protection of exploitation already in progress. A landowner does not have precedence to an exploitation licence for minerals on his or her own land, unless he or she has previously been issued a prospecting and exploration licence.

For those who wish to prospect and explore for minerals on somebody else's land, including that of the state, a licence is needed. The licence gives sole right to prospecting and exploration in the designated area. Before the National Energy Authority can grant the licence, it shall obtain an opinion from two or three relevant sector authorities.

There is currently one valid licence for metal prospecting and exploration in Iceland, with focuses on gold. The licence was granted 2004, and then extended in 2008, 2011 and 2014. It is currently valid until $2016 . .^{53}$ The licence initially covered fourteen huge areas, which were located in different parts of Iceland. In 2010, this was reduced to nine.

\footnotetext{
51 This and following quotes from the Act on the Survey and Utilisation of Ground Resources are taken from a translated version of the document, which can be found on the Icelandic Government's official website: http://eng.atvinnuvegaraduneyti.is/media/acts/Act-No-57-1998-on-survey-and-utilisation-of-groundresources.pdf

52 The Act does not differentiate between prospecting or exploration permits.

53 Information from the Icelandic National Energy Authority.
} 
A licence is needed for any party who wishes to exploit minerals on public land or on land owned by somebody else. The licence is also granted by the National Energy Authority. According to section 17 of the Act, care should be taken that the exploitation of minerals is carried out in a manner which takes into consideration environmental viewpoints, is efficient from a macro-economic point of view, and that takes account of any exploitation already in progress in the vicinity. If the applicant does not meet these requirements, the National Energy Authority may refuse to grant the licence or insert special conditions therein. Before a licence is granted, an opinion shall be obtained from two or three relevant sector authorities, as well as the local government in question.

Both prospecting and exploration, and exploitation licences shall specify, inter alia, which resources are covered and how much; quantity and rate of extraction; an approval from the National Energy Authority on the preliminary drawings of any proposed structures; the obligation of the licence holder to inform and notify; safety and environmental protection measures; insurance for any potential liability of the licence holder for damages; monitoring and payment of cost of monitoring; payment of licence fee to meet the cost of the preparation and issue of the licence; the manner of disposal of extracting structures and extracting equipment following the end of the licence term, and; clean-up of work areas and land that has been altered in the course of prospecting, exploration or exploitation.

\subsubsection{Other provisions in the Act on the Survey and Utilisation of Ground Resources}

An exploitation licence holder is required to reach an agreement with the private landowner on compensation for the minerals. Alternatively, the Minister of Industry and Commerce may expropriate the land and rights necessary from the landowner, according to provisions in chapter $\mathrm{X}$ of the Act. In the event that neither an agreement has been made nor expropriation requested within 60 days following the date of issue of the licence, the latter shall be cancelled. On land owned by the state, the Minister of Industry and Commerce may negotiate with exploitation licence holders on remuneration for minerals after consulting with the party administering the property.

The Act further specifies that both landowners and licence holders shall take care that mineral prospecting, exploration and exploitation does not cause any danger or damage to persons, moveable property or 
livestock, or pollution and damage to the biosphere. Also, the Act contains provisions on the monitoring and reporting of activities, as well as possibilities to appeal decisions.

\subsubsection{Other legislation and permits}

The third paragraph of article 1 of the of the Act on the Survey and Utilisation of Ground Resources notes that "[s]urvey and exploitation pursuant to this Act are subject also to the Nature Conservation Act, Planning and Building Act and other acts relating to the survey and exploitation of land and land benefits". For example, according to article 31 of the same Act, an additional licence pursuant to the provisions of the Act on Public Land is needed in case of exploitation of resources on public land.

The Nature Conservation Act of 1999 contains a number of general provisions that are of relevance to the minerals industry, but also some that are specific. Chapter VI focuses on the extraction of materials from the earth. Article 47 presents provisions around permitting of extraction of materials including minerals. In addition to any permits required according to the Act on the Survey and Utilisation of Ground Resources, "[a]ll extraction on land and from or under the seabed within the netlaying area, shall be subject to the operating permission of the local authority concerned, cf. Article 27 of the Planning and Building Act, No. 73/1997". ${ }^{54}$ For seabed areas beyond the net-laying area, i.e. 115 metres from the shore, permitting is done pursuant of the Act on the Ownership of the Icelandic State of Resources on the Seabed. Both this Act and the Planning and Building Act will be revisited briefly below. Landowners or right-holders of private property may however undertake limited extraction for personal use without a special permit, except in cases of landscape formations that enjoy special protection.

According to article 48 of the Nature Conservation Act, before extraction can be permitted as mentioned above, a plan must be provided which includes information on the quantity and type of material, the processing time, and clean-up of the extraction area. The Environment Agency shall maintain surveillance of the extraction of land, and may also demand security to cover estimated costs of this as well as future

54 This and following quotes from the Nature Conservation Act are taken from a translated version of the document, which can be found on the Icelandic Government's official website: http://eng.umhverfisraduneyti.is/ legislation/nr/389 
clean-up. The subsequent article deals with rehabilitation of areas in more detail.

Other parts of the Nature Conservation Act are also of relevance for the minerals industry, including articles 33 and 34. The former states that " $[t]$ he opinion of the Nature Conservation Agency and nature conservation committees shall be sought [...] when drawing up detail plans and master plans and making substantial changes to them and when rulings on environmental impact assessments are issued". 55 And according to article 34, "[m]ajor projects, which affect the environment and change its appearance, such as alteration of land with earthfill, or extraction, shall comply with zoning plans and the ruling on environmental impact assessment, where applicable".

In turn, the Planning and Building Act includes provisions on the granting of development permits and building permits. Here, article 27 reads that "[s]ubstantial development projects which have an effect on the environment and change its appearance, alteration of land by changing its soil or the removal of material, shall be in accordance with development plans and decisions on environmental impact assessments, where appropriate". ${ }^{56}$ The Environmental Impact Assessment Act of 2000 lists activities that shall always be subject to EIA, and activates which are subject to EIA depending on the characteristics of the project, location, and the characteristics of the potential effects. Among the former are quarries of a certain size, whereas certain smaller quarries and underground mines belong to the latter category.

As mentioned earlier, the Act on the Ownership of the Icelandic State of Resources on the Seabed covers areas beyond 115 metres to the shore, as far out as Icelandic sovereignty does according to international law and agreements with individual countries. According to article 1, the Icelandic state is the owner of all resources under the seabed covered by the Act. Exploration or exploitation of those resources requires a permit from the National Energy Authority. Before a permit can be granted, an opinion shall be gathered from the Environment Agency. The Act fur-

55 Nature conservation committees are elected by local councils and responsible for promoting nature conservation in their own areas, for instance, through public instruction and discussion of projects and activities likely to affect the natural environment, and make proposals for improvements to the local authorities and the Nature Conservation Agency. See article 11 of the Nature Conservation Act.

56 This quote from the Planning and Building Act is taken from a translated version of the document, which can be found on the Icelandic Government's official website: http://www.skipulagsstofnun.is/media/ skipulagsmal/Planning-and-Building-Act.PDF 
thermore includes provisions around regulations of activities, as well as actions to prevent pollution.

\subsection{Norway}

In 2013, there were three metal mines in production Norway, with a turnover of NOK $2.7 \mathrm{bn}$. Additionally, turnover of gravel, hard-rock aggregate and clay was NOK $5.4 \mathrm{bn}$, that of natural stone NOK $1.1 \mathrm{bn}$, and that of industrial minerals NOK $2.4 \mathrm{bn}$. In the same period, coal production on the archipelago of Svalbard had a turnover of NOK $1.3 \mathrm{bn}$. The whole industry employed 6,226 persons, of which 1,245 in metal mining.

Like Finland, Greenland and Sweden, Norway has developed a national strategy for the minerals industry, which was published by the former government in 2013. The document states that the government's objective is that "[g]rowth in the industry shall be strengthened by means of a continued commitment to mapping of mineral deposits, access to information about mineral resources in Norway, better resource planning, a continued development of the mineral agencies and access to knowledge and a competent workforce". ${ }^{57}$ The strategy includes over fifty measures, focused around the following strategic areas: mapping mineral resources; investment and access to capital; education and expertise; research and development; safeguarding environmental concerns; reputation, social responsibility and the local community; a predictable framework for mineral operations in Norway; subsea mineral resources, and; mineral activities in areas where there are Sami interests.

The Norwegian Minerals Act was adopted in 2009, replacing five earlier laws. As applications filed prior to its adoption have been tried under the former law, it is still early to draw general conclusions on the effects of the new Act. This can be compared to a similar situation in Finland, following the even more recent adoption of a new Mining Act there.

Norway is not a member of the EU, but is closely associated through membership of the European Free Trade Association (EFTA) and thereby the European Economic Area (EEA). An exception is the archipelago of Svalbard, which is excluded from the EEA agreement. However, Norway follows EU legislation related to the single market, except laws on

${ }^{57}$ Norwegian Ministry of Trade and Industry (2013). Strategy for the Mineral Industry. Oslo: Norwegian Ministry of Trade and Industry, 17. 
agriculture and fisheries. Potentially the country has a right to reserve itself against adopting EU legislation, but this possibility has only ever been used once. Notably, environmental legislation is very much influenced by the EU. So far, more than 250 environmental acts have been incorporated into the EEA agreement. ${ }^{58}$

\subsubsection{Permits according to the Minerals Act}

The first section of the Norwegian Minerals Act stipulates the objective of the Act, which is to "promote and ensure socially responsible administration and use of mineral resources in accordance with the principle of sustainable development". ${ }^{59}$ Furthermore, section 2 states that " $[w]$ ithin the framework of section 1, the administration and use of mineral resources pursuant to this Act shall ensure that the following interests are safeguarded: a) value creation and industrial and commercial development; b) the foundation of Sami culture, commercial activity and social life; c) the surroundings and nearby areas while operations are being carried out; d) the environmental consequences of extraction; and e) long-term planning relating to subsequent use or reclamation of the area." Notably, sections 1 and 2 are comparable to the similar section 1 of the Finnish Mining Act.

Prospecting and exploitation of all minerals is covered by the Norwegian Minerals Act. The Act differentiates between state-owned and landowner minerals. The former is defined as those minerals with density above $5 \mathrm{~g} / \mathrm{cm}^{3}$. In other words, some more minerals are classified as belonging to the landowner than in Finland and Sweden. Another difference is that the Norwegian Minerals Act covers the exploration and exploitation of both landowner and state-owned/controlled minerals, whereas they are covered by separate laws in the Finnish and Swedish case. Notably, the Minerals Act is not applicable to the archipelago of Svalbard, and special provisions apply in the county of Finnmark. This will be covered in more detail later on.

Chapters 2 to 4 cover mineral searching and exploration. Like in other Nordic countries, limited prospecting does not require a permit. Exceptions to this rule explicitly mentioned in the Act are the protected

\footnotetext{
58 http://www.eu-norway.org/eu/policyareas/Environment/\#.VL46_aMV-M8

59 This and following quotes from the Minerals Act and related Ordinance are taken from translated versions of the documents, which can be found on the Norwegian Government's official website: https://www.regjeringen.no/en/aktuelt/The-Minerals-Act-available-in-English/id606042/
} 
nature areas around Oslo, cultivated lands, industrial or military areas, areas close to temporary or permanent residences or to public facilities, and abandoned mining areas. Searching and exploration in those areas may be allowed upon agreement with the landowner, land user or relevant authority. Furthermore, any activity that may cause significant damage requires consent from the landowner and land user. The latter two groups are to be informed before searches are conducted.

Beyond searching, exploration of landowner minerals requires an agreement between the explorer and the landowner. If an agreement has not been reached, an application can be sent to the Directorate of Mining for the right to acquire compulsorily the land and rights needed to explore. Furthermore, pilot extraction also requires a specific permit from the Directorate, to which conditions may be attached. Before a permit is granted, the landowner, the land user, the county governor, the county municipality and the municipality are given an opportunity to comment. Like for exploration, extraction of landowner minerals necessitates an agreement with the landowner. If an agreement cannot be met in this case, an application concerning compulsory acquisition of the deposit, land and rights shall be sent to the Ministry of Trade, Industry and Fisheries.

For exploration of state-owned minerals, a permit from the Directorate is needed. An exploration permit also gives priority to an extraction permit later on. Information on format requirements on exploration permit applications, as well as rights and limitations associated with permits, are found both in the Minerals Act and in regulations issued by the Ministry of Trade and Industry. Special provisions apply in Finnmark, which we will revisit shortly. Prior to starting exploration, the Directorate, landowner and land users are to be informed and presented a work plan. Here again, pilot extraction necessitates a permit from the Directorate.

In order to be granted an extraction permit for state-owned minerals, the applicant needs to show that there is a reliable chance that extraction can be done in an economically feasible manner. Provisions on compulsory acquisition of land and rights are similar to those for extraction of landowner minerals. However, mining usually cannot commence with an extraction permit alone. Regardless of type of mineral, the Directorate of Mining must be notified in case of extraction of more than 500 cubic metres of matter. In special cases, the Directorate may require the submission of a plan of operations. For extraction of minerals exceeding 10,000 cubic metres, an operating licence is needed. This also applies to all cases of natural stone extraction. 
The operating licence is granted by the Directorate of Mining. Notably, section 43 of the Act states that "the assessment of whether an operating license should be granted, emphasis shall be given to whether the applicant is qualified to extract the deposit". Chapter 3 and 4 of the regulations issued pursuant of the Minerals Act by the Ministry of Trade and Industry present detailed provisions on what kind of qualifications are needed to work as a mining engineer in charge.

In addition to information on what qualifications are at the applicant's disposal, the operating licence application shall include a work plan in accordance with guidelines from the Directorate, an assessment of adequate security to be provided, and an overview of planned investments and financing. Furthermore, the application shall give information on how the relevant area is currently regulated in the municipal master plan, and if the project is or will be covered in a local development plan. The plans are developed in accordance with the Planning and Building Act, which we will revisit shortly.

\subsubsection{Provisions regarding Finnmark and Samis}

Norway is home to the largest Sami population in Scandinavia, estimated between 40,000-60,000 persons. Like in Sweden but unlike in Finland, Norwegian Samis exercise exclusive rights to reindeer herding. The Norwegian Sami Parliament was inaugurated in 1989, and Norway ratified ILO Convention 169 in 1990. This has since been implemented into Norwegian law first and foremost through the special Finnmark Act.

The Finnmark Act was adopted by the Norwegian Parliament in 2005 with the aim to promote sustainable natural resource management and Sami culture, and the rights of Sami as well as non-Sami residents of Finnmark. As a result of the act, ownership of around 95\% of Finnmark was transferred from the state-owned land and forest enterprise Statskog to the then-established Finnmark Estate. The board of the Finnmark Estate consists of three persons chosen by the Norwegian Sami Parliament, and three persons chosen by the locally-elected County council. Furthermore, a committee of three persons, one each chosen by the Norwegian government, Sami Parliament and Finnmark Councy council, is tasked to control that the Finnmark Estate follows the Finnmark Act and other relevant legislation.

The Minerals Act section 6 states that " $[\mathrm{t}]$ he Act shall be applied in accordance with the rules of international law relating to indigenous people and minorities". The Act includes specific provisions that apply in Finnmark. In the searching phase, section 10 on the duty to give notice 
states that "[i]n the case of a search in Finnmark, the searching party shall in addition give written notice to the Sameting (the Sami Parliament), Finnmarkseiendommen (the Finnmark Estate) where it is landowner, and the relevant area board and district board for reindeer management. Whenever practically possible, the siidas ${ }^{60}[\ldots]$ shall be given oral notice". ${ }^{61}$ Furthermore, section 17 states that exploration of stateowned minerals in Finnmark necessitate special permit from the Directorate of Mining, beyond the regular exploration permit. The rest of the section reads the following:

\footnotetext{
"An exploring party shall take reasonable steps to obtain information about directly affected Sami interests in the area that is to be explored.

A special permit may be refused if granting the application would be contrary to Sami interests. In the assessment, special consideration shall be given to the interests of Sami culture, reindeer management, commercial activity, and social life. If the application is granted, conditions may be imposed to safeguard these interests.

When processing the application, the Directorate of Mining shall give the landowner, the Sameting (the Sami Parliament), the municipality, and the relevant area board and district board for reindeer management an opportunity to comment.

If the Sameting or the landowner opposes the granting of an application, the Ministry shall decide the application.

If the Ministry grants an application [...], an appeal to the King by the Sameting or the landowner shall have a suspensive effect."
}

Similar provisions also cover pilot extraction (sections 12 and 20), extraction permits (section 30), expropriation (section 40), and operating licences (section 43).

It is worth noting that the Norwegian Sami Parliament did not support the adoption of the new Minerals Act in 2009. Main arguments were that the increased landowner fee for operation in areas owned by the Finnmarkseiendom is not adequate to fulfil the ILO Convention 169 provisions on indigenous peoples' rights to benefits and compensations from natural resource exploitation, and that the current Act does not give Sami interests equal protection outside of Finnmark county. ${ }^{62}$ In 2001, a process was initiated by the government with the aim to examine Sami rights outside of Finnmark. An official report was pub-

\footnotetext{
${ }^{60} \mathrm{~A}$ reindeer herding society.

${ }^{61}$ See similar provisions in section 18

${ }^{62} \mathrm{http}$ ///www.nrk.no/sapmi/ny-minerallov-tross-protester-1.6535185
} 
lished in 2007, "The New Sami Legal Regime", but it has yet to be translated into new rights for the Sami people in other parts of Norway.

\subsubsection{Other provisions in the Minerals Act}

The Minerals Act and related regulations include a number of provisions on taxation and fees, which is covered in more detail later on in this report as well as in Appendix A. They also provide provisions on supervision of activities, as well as administrative and enforcement measures and sanctions. On the other hand, unlike the Finnish and Swedish Acts, the Norwegian Minerals Act does not contain detailed provisions on how to appeal decisions.

According to section 48 of the Norwegian Minerals Act, there is a general duty to exercise caution when carrying out operations. The following two sections state that exploring or extracting parties have a duty to implement and maintain safety measures so that the operations do not pose a danger to humans, farm animals or domestic reindeer; and that they have a duty to clean up both during and after operations. If the landowner or land user demands so, a party exploring state-owned minerals has to provide security in order to cover for safety measures and clean up. The Directorate may also require permit holders to provide security. In case the relevant parties have not been able to come to an agreement, the size of the security is settled by a special court of assessment. According to regulations from the Ministry of Trade and Industry, security according to the Minerals Act shall be coordinated with security according to the Pollution Control Act, if applicable. We will look briefly at this next.

\subsubsection{Other legislation and permits}

The Norwegian Minerals Act section 5 notes that "[p]ermits issued pursuant to this Act do not replace requirements in other legislation for permits, approvals, land use plans or licences. Searches for, exploration of, extraction of and operations on, mineral deposits may only take place subject to the limitations imposed by this Act and other legislation".

An important law in this regard is the Planning and Building Act of 2008 which explicitly states that plans shall "protect the natural basis 
for Sami culture, economic activity and social life". ${ }^{63}$ An operating licence from the Directorate of Mining is generally dependent on a mining project being in accordance with municipal plans. ${ }^{64}$ According to preparatory works from the government for new Minerals Act, the municipality as authority for local planning is responsible for making a final decision on whether or not mineral extraction shall allowed. All those who wish to commence mining therefore have apply to the municipality for regulating the area for mining activities, unless the area already has such status. ${ }^{65}$

The main EIA is generally conducted as a part of the municipal planning process. According to the Ministry of Trade and Industry guide to the Norwegian Minerals Act, the planning process including the EIA is generally more detailed and time-consuming than the operating licence application. Normally it involves hearings with several interested parties. For example, the Sami Parliament has a right to express its opinion on planning issues that are of importance for Sami culture or commercial activities according to section 5-4 of the Planning and Building Act. The Ministry recommends that the planning process be handled in parallel with applications for other necessary permits. ${ }^{66}$

Provisions on the EIA are found in regulations issued by the Ministry of Local Government and Modernisation pursuant of the Planning and Building Act. A significant challenge is the fact that EIA processes may sometimes be overwhelming for small municipalities; a one-off event for which they do not have adequate routines or competence. This has also been noted in the national strategy for the minerals industry. ${ }^{67}$

Environmental legislation that plays an important role includes the Nature Diversity Act and the Pollution Control Act. The purpose of the former "is to protect biological, geological and landscape diversity and ecological processes through conservation and sustainable use". 68 The Act affirms principles such as the precautionary principle, polluter pays, and best available technique. For mineral development, the Nature Diversity Act has an impact through guiding legal interpre-

\footnotetext{
63 Planning and Building Act, section 3-1.

64 Ministry of Trade and Industry (2011). Veileder til mineralloven. Oslo: Ministry of Trade and Industry, 22.

65 Ministry of Trade and Industry (2009). Ot.prp. $n r .43$ (2008-2009). Om lov om erverv og utvinning av mine-

ralressurser (mineralloven). Oslo: Ministry of Trade and Industry, 46.

66 Ministry of Trade and Industry (2011). Veileder til mineralloven, 39.

${ }^{67}$ Ministry of Trade and Industry (2013). Strategy for the Mineral Industry, 63.

${ }^{68} \mathrm{https}$ ://www.regjeringen.no/en/dokumenter/nature-diversity-act/id570549/
} 
tation and decision-making according to other sector laws, such as the Minerals Act.

The Pollution Control Act regulates emissions such as noise, dust, chemicals, heavy metals, greenhouse gases et cetera. Generally, pollution permits for the extraction of state-owned minerals are granted by the Norwegian Environment Agency, while the County Governor is responsible for industrial minerals. For gravel and hard-rock aggregates, special provisions according to regulations pursuant of the Pollution Control Act are applicable. Conditions are attached to permits. For projects that entail a larger amount of emissions, an EIA according to the Act is needed. However, this is often coordinated with the planning process so that there is only need to conduct one EIA. ${ }^{69}$

Pursuant, inter alia, to the Pollution Control Act, the Ministry of Climate and Environment has issued regulations that cover mining waste and thereby transpose the Mining Waste Directive (2006/21/EC). This includes provisions on permitting of mining waste management. Although controversial, the possibility to dump mining waste in fjords is of importance for the Norwegian mining industry, for obvious geographic reasons. Here, the Water Regulation plays a key role.

Beyond environmental laws, another notable part of the Norwegian legal framework around mining governs activities on the archipelago of Svalbard. The Norwegian Minerals Act is not applicable there, according to its section 4. Under the 1920 Svalbard Treaty, the archipelago of Svalbard falls under Norwegian sovereignty and is governed by Norwegian law albeit with a number limitations. The treaty also guarantees that other signatory countries have non-discriminatory right to exploit the archipelago's natural resources. Today, of the four active coal mines on Svalbard, three are run by the state-owned company Store Norske Spitsbergen Kulkompani AS, and one is run by the Russian state-owned mining company Arktikugol. The latter mine is located in the community of Barentsburg, which is inhabited mainly by Russians and Ukrainians.

The Commissioner of Mines on Svalbard represents the state in relation to the petroleum and mining activities, and also functions as expert for the Ministry of Trade and Industry in matters relating to mining on Svalbard. Since 2003, the Commissioner forms a part of the Directorate of Mining. The Commissioner is main authority responsible for administrating the Mining Code for Spitsbergen (Svalbard) laid

${ }^{69}$ Ministry of Trade and Industry (2011). Veileder til mineralloven, 42. 
down by Royal Decree of 7 August 1925. Section 2 of the Code states that all persons and companies from countries that have ratified the Svalbard Treaty have a right to search, gain and exploit coal and other minerals. Furthermore, the Code includes provisions on, inter alia, where mining activities may not be undertaken, compensations in case of damage on somebody else's property, administrative process fees, rights and obligations of licence and claim holders, the manner in which mining shall be conducted, and the protection and conditions of workers, including the requirement that employees furnish workers with healthy and property dwellings as well as sanitary arrangements.

A licence is needed in order to conduct searches on somebody else's or state-owned land, and the licence gives right to undertake any work necessary for examining discoveries. In turn, anybody who by lawful search has discovered a natural deposit has priority to a later claim through sending the Commissioner a discovery notice. After this, the Commissioner conducts a survey in order to establish the claim, which gives the holder the sole right to extract the minerals covered. The landowner is entitled to a participation of up to a quarter of the operation, if he or she so wishes.

In addition, Svalbard is also covered by other special laws of relevance for mining. One example is the Svalbard Environmental Protection Act. The Norwegian Labour Inspection Authority has issued specific regulations for the coal mines on Svalbard pursuant of the Working Environment Act.

Finally, as in other Nordic countries, a number of other laws also play an important role in regulating mining activities. In the permitting phase, these include the Cultural Heritage Act, the Motor Traffic on Uncultivated Land and in Watercourses Act, the Reindeer Herding Act et cetera, as well as a number of laws which regulate work environment, taxation and reporting. Finally, an issue which may be of increasing interest in the future in Norway, like Iceland, is underwater mining. One of the areas of interest here is the aforementioned Mid-Atlantic Ridge, which in addition to Iceland runs through the Norwegian island of Jan Mayen. Currently, legislation and regulations around underwater mining has yet to be further developed. The Act on the Scientific Exploration for and Exploitation of Underwater Natural Resources other than Petroleum of 1963 states that all underwater resources belong to the state. ${ }^{70}$ The

${ }^{70}$ Author's translation. 
King has the right to grant the right to explore or exploit such resources. Also, the King may instruct county councils to exercise authority with regards to the exploration and exploitation of underwater shell sand, sand and gravel.

\subsubsection{Other notes}

Norway has committed itself to following the Extractive Industries Transparency Initiative (EITI) standard. The standard requires companies in the extractive industries to fully disclose taxes and other payments made to governments. These payments are disclosed in an annual EITI Report. The majority of those committed are resource-dependent developing countries. Norway is a member because of its large oil and gas sector, which made up $21.5 \%$ of the country's GDP in 2013 and almost half of total exports. At the same time the mineral sector constitutes less than one percent of GDP, and is therefore exempted from EITI reporting due to relative insignificance. ${ }^{71}$

Norwegian Mineral Industry is the minerals sector company association, which was established in 2008. Ethical guidelines were adopted at the inaugural meeting of the association, and the guidelines are mandatory for all its members. The guidelines focus on work conditions, efficient resource utilisation, and relations with stakeholders including indigenous people. In case of transgression, the association may express dissatisfaction with the member's behaviour, or even resort to exclusion. This has not happened to date.

Finally, one large issue of contention surrounding the minerals industry in Norway is submarine tailings disposal. This is obviously more interesting for the Norwegian minerals industry than for its counterparts in Finland and Sweden due to the proximity to the fjords and ocean.

\subsection{Sweden}

Sweden has the largest mining sector of the Nordic countries today. In total, there are 15 metallic mineral mines, and around 6,300 persons are directly employed by mining companies. In 2013, a total of 130 exploration permit concessions were submitted, compared to 211 the year be-

${ }^{71}$ https://eiti.org/validation-report-norway 
fore. According to the 2014 Fraser Institute survey of mining and exploration companies, Sweden ranks as having the fourth most attractive mining policy worldwide.

The Swedish Government has also taken steps to improve Sweden as a destination for mining. In 2013, it presented a minerals strategy. According to the Government, the strategy "will increase the competitiveness of the Swedish mining and minerals industry so that Sweden maintains and strengthens its position as the EU's leading mining nation. Sweden's mineral assets are to be exploited in a long-term sustainable way, with consideration shown for ecological, social and cultural dimensions, so that natural and cultural environments are preserved and developed". In total, the strategy proposes 19 measures which aim, inter alia, to increase resource efficiency, improve dialogue and synergy with other industries, promote regional growth, improve distribution of responsibility, clarify and create a more effective regulatory framework, facilitate investments in infrastructure, promote research and innovation, ensure supply of skills and capital, and increase participation in the international arena.

The main legislation governing mining activities in Sweden is the Minerals Act. The act dates back to 1991, but has been revised on a number of occasions since then, reflecting different political priorities. ${ }^{72}$ For example, in order to promote exploration and mining, the right of the Crown to half a share in mines was removed in 1993, and the validity of exploration and exploitation concessions have been extended. In order to improve the situation for landowners, compensation equal to $0.15 \%$ of the value of the minerals extracted has been introduced together with a share of $0.5 \%$ to the government. The Minerals Act has been adapted to the new Environmental Code of 1998, which replaced a number of environment acts. And finally, the purpose of the latest revision of the act, in 2014, was to ensure that those affected by exploration works receive adequate information from the permit holder, which notably includes Samis.

The following section will focus on the permitting process which is governed according to the Minerals Act. In addition, there are also a number of other laws of relevance with regards to mine development, such as the Planning and Building Act, the Environmental Code and the Heritage Conservation Act. These will be revisited briefly later on.

72 See Liedholm Johnson (2010). Mineral rights: Legal systems governing exploration and exploitation. 


\subsubsection{Permits according to the Minerals Act}

Like in most other Nordic countries, Swedish legislation differentiates between landowner minerals and so-called concession minerals. ${ }^{73}$ The exploitation of landowner minerals, which include a number of industrial minerals, is governed under the Environmental Code. For other, socalled concession minerals, the Minerals Act applies. ${ }^{74}$

Swedish law differentiates between exploration and exploitation of minerals. Following the Nordic tradition of freedom to roam, anybody has the right to search for minerals on the ground under certain limiting conditions. However, with an exploration permit the holder has an exclusive right to explore for minerals in an area, as well as priority to a permit for exploitation of the identified minerals. In order to obtain an exploration permit, an application as well as a work plan has to be submitted to and approved by the Mining Inspectorate. The relevant municipality, County Administrative Board and, in reindeer herding areas, Sami Parliament, have the right to be informed and express their opinion on the application, according to the Minerals Ordinance. For certain activities, such as exploration in or close to nature reserves or exploration that entails test mining, additional permits from other authorities may be needed.

The applicant has to provide a certain amount of financial security to cover any damage caused. The approval of the landowner is usually not needed for a permit to be issued. However, the landowner as well as other interested parties have a right to be informed about the work plan and express their opinion or opposition. The work plan shall include information on possible impact of exploration work on both individual and public interest, what damage can be caused and what subsequent collateral exists. In case the permit applicant and interested parties are not able to come to an agreement over the work plan, it is tried by the Mining Inspectorate.

In order then to exploit a mineral, an exploitation permit is needed. This is also mainly governed under the Minerals Act and granted by the Mining Inspectorate. The main task of the Mining Inspectorate in the

\footnotetext{
73 The law does not state that the concession minerals belong to the government. Bäckström (2012) has considered the issue of ownership of concession minerals in his doctoral thesis. He concludes that they principally belong to the landowner, and the Minerals Act therefore functions as a legal constraint to his or her rights. Bäckström, Lars (2012). Rätten till mineral: en studie om befogenheter och legala inskränkningar $i$ äganderätten till fastighetens beståndsdelar. Luleå: Luleå University of Technology.

74 The following section is based on a recent guideline for how mining activities are legally examined. Geological Survey of Sweden (2013). Vägledning för prövning av gruvverksamhet. Uppsala: Geological Survey of Sweden.
} 
case of an exploitation application is to consider the economic feasibility of extracting the identified minerals (i.e. whether or not they constitute an ore), as well as whether the land should be used for mining or for some other competing purpose in order to best promote a sustainable development. The latter is also known as the resource management provision, which is based on chapter 3 and 4 of the Environmental Code.

Chapter 3 therein lists a number of land uses that may be of national interest, which include nature conservation, agriculture, defence, energy production, reindeer husbandry and mineral exploitation. Section 1 of the chapter states that "[1] and and water areas shall be used for the purposes for which the areas are best suited in view of their nature and situation and of existing needs. Priority shall be given to use that promotes good management from the point of view of public interest". According to section 10 though, the needs of national defence has priority over other competing land uses. In the following chapter 4, a number of areas in Sweden are identified as national interest as well. Section 1 specifies that the provisions of the chapter shall not hinder the development of existing urban areas or local industry, or the construction of installations that are needed for the purposes of national defence. Furthermore, where special circumstances exist, the provisions in chapter 4 shall not prevent the erection of structures for the extraction of mineral deposits of national interest. Sector authorities are responsible for identifying areas of national interest. The Mining Inspectorate shall also take into consideration if the area in question has been regulated for some other purpose by the municipality according to the Planning and Building Act.

It is mandatory for the Mining Inspectorate to consult with the County Administrative Board on issues of land use and environmental impact, which in turn often consults with municipalities and other government agencies. Other stakeholders are also to be informed and allowed to express their opinion at this point. An EIA has to be conducted, however this is limited in contents and focuses more explicitly on land use, whereas a larger EIA is to be conducted later on as a part of the environmental permitting phase. These EIA processes also differ in consultation requirements, which are more extensive for the latter. ${ }^{75}$ If possible, conditions may be attached to an exploitation permit so to allow for the co-achievement of different land use purposes. If the Mining Inspec-

75 Pettersson et al. (2015). License to Mine: a comparison of the scope of the environmental assessment in Sweden, Finland and Russia. 
torate and County Administrative Board disagree on land use, or if the applicant or affected stakeholder disagrees with the permit decision, the Government may try the case. According to the Minerals Act, a permit granted by the Mining Inspectorate may also be appealed to the Government by relevant municipalities and by environmental NGOs that fulfil certain criteria. ${ }^{76}$ However, the Government may even decide to try cases appealed by other parties.

Other permits are also needed in order to open a mine, for which provisions are found in other laws. This will be revisited shortly. The Minerals Act also includes provisions on the allocation of land. Accordingly, in cases where there is no agreement between the exploitation permit holder and the owner of land necessary for mining operations, the Mining Inspectorate may decide on land allocation.

\subsubsection{Provisions regarding Samis}

Sweden, like Finland and Norway, is also home to the Sami people. The population is estimated to number between 20,000 and 40,000 persons, ${ }^{77}$ and the Swedish Sami Parliament was inaugurated in 1993. Like in Norway but unlike Finland, Samis in Sweden exercise exclusive right to reindeer herding. The right is reserved to members of a "sameby", an economic association which is entitled to practice reindeer herding in a designated area.

The Minerals Act does not include any explicit references to Sami rights or reindeer herding, unlike its Finnish and Norwegian counterparts. The Minerals Ordinance specifies that the Sami Parliament shall be informed on applications and decisions on exploration and exploitation permits. However, areas of national interest for reindeer herding are protected through the Environmental Code, and the Sami Parliament is responsible agency for identifying such areas. Notably, these areas may overlap with other national interests, as designated by other agencies, in which case the exploitation permit process is supposed to decide on which land use best contributes to sustainable development. This includes inter alia national defence, energy production (e.g. wind power), nature conservation, but also mineral exploitation.

\footnotetext{
76 The main criteria are that NGOs shall be non-profit, must have been active in Sweden for at least three years, and have at least 100 members or broad public support. See Environmental Code, chapter 16, section 13. 77 http://www.sametinget.se/kortfakta
} 
According to chapter 3 section $5 b$, landowners or land users may request a translation of the exploration work plan in the minority languages Finnish, Meänkieli or Sami. This right applies to certain areas of Sweden, as designated according to the Act on National Minorities and National Minority Languages of 2009.

\subsubsection{Other legislation and permits}

In order to open a mine, an environmental permit under the Environmental code is needed, which is granted by the Land and Environment Courts. An environmental permit may also be needed if test mining is to be conducted within the framework of an exploration permit. Prior to submitting an application for an environmental permit, affected stakeholders, municipalities and government agencies are to be consulted. The aim is to clarify issues at an early stage, and to allow for discussions and possible modifications of plans in order to minimise negative impact. Here as well, an EIA is also to be conducted. It differs from the previous EIA in that the former has a more limited focus on alternative land uses and, unlike the EIA conducted under the Environmental Code, does not require stakeholder consultations (although this is recommended). There is no legal requirement to establish a Social Impact Assessment, although some companies have done this nonetheless. One study indicates that the reason for the more voluntary SIAs may be influence from international trends. ${ }^{78}$

After receiving the application, a process starts whereby the Land and Environmental Court tries the application. This involves several stages of consultations and negotiations, which ultimately may lead to the approval of the permit and setting of environmental conditions for the subsequent mining activities. This may include e.g. limits to emissions as well as establishment of security for environmental rehabilitation. Decisions may be appealed to a higher court. Decisions on permitting of uranium mining are tried by the Government, according to the Environmental Code. The Government can however only permit uranium mining if the relevant municipality has given its consent.

${ }^{78}$ Tarras-Wahlberg, Håkan (2014). Social license to mine in Sweden: do companies go the extra mile to gain community acceptance? Mineral Economics 27.2-3. 
A special permit is needed in order to conduct mining activities in Natura 2000-areas, or for activities that may affect such an area. This is granted by the County Administrative Board. Finally, a building permit and possibly even a site improvement permit are necessary for commencing mining, which are issued by the local municipality in accordance with the Planning and Building Act of 2010. The scope of this permitting process depends on a number of factors. For example, separate laws stipulate requirements for the planning of road and railroad construction.

Once all permits are in place and construction of the mine can commence, new issues obviously arise. This includes important sustainability issues such as organisational health and safety, taxation and reporting. For example, environmental conditions attached to permits according to the Environmental Code are reported on annually. The County Administrative Board and municipality are most often responsible for follow-up, including through environmental inspections. Similarly, companies are obliged to report in case of serious accidents. On the other hand, while there has been a trend towards including more "soft" issues in EIA reports, such as impact on local social structures, there is generally no commensurate follow-up or reporting once mining has commenced.

\subsubsection{Other notes}

The Swedish Minerals Act is notably shorter than its Finnish counterpart. The latter includes more provisions on issues such as health and safety, environmental concerns and Sami rights, which in the Swedish case are found in legislation outside of the Minerals Act.

The Swedish permitting system has been criticised from different perspectives. On the one hand, mining differs from other industrial activities in that the question of land use is to be settled separately from other environmental concerns. The potential environmental impact of a mining project is less known at this stage than in the subsequent environmental permitting procedure, but nonetheless the Mining Inspectorate and County Administrative Board are tasked to weigh competing land use options against each other. The environmental permitting procedure is thereby limited to primarily being a process for setting limit conditions for mining activities. This can be contrasted e.g. to Finland, where environmental concerns are to be considered in assessments for a 
mining permit. At the same time, the process is also criticised for being slow, cumbersome and unpredictable. ${ }^{79}$ And furthermore, there has been extensive critique of how stakeholders are involved in the process. In many cases the law is limited to requiring stakeholders to be informed and allow them to express their opinion. However, permit applicants are recommended to go further than the minimum requirements in their stakeholder contacts, ${ }^{80}$ and voluntary guidelines for dialogue and consultations have been developed. ${ }^{81}$

Finally, companies who are member of the Swedish mining industry association are obliged to become signatories to the association's ethical rules. The rules are broadly formulated, and focus on work environment, physical environment, risk management, and transparency and reporting. Furthermore, signatories shall promote compliance to the ethical rules among their contractors, and they shall actively educate their employees and support research in order to improve performance. The ethical rules are signed by company CEOs. So far, no company has been excluded from the association due to breech of the ethical rules.

\footnotetext{
${ }^{79}$ Aaro, Lars-Eric et al. (2012). Ge gruvorna chansen. Stockholm: Dagens Industri. http://www.di.se/artiklar/2012/1/30/debatt-ge-gruvorna-chansen/

${ }^{80}$ See e.g. Geological Survey of Sweden (2013). Vägledning för prövning av gruvverksamhet, 55

${ }^{81}$ Georange (2011). Georanges vägledning för samråd \& dialog. Georange.
} 


\section{Taxation review}

Taxation of mining deserves a particular comment. Generally, it is difficult to compare the level of mining taxation in different countries. One common method is to compare levels of corporate tax, royalties, VAT, environmental taxes and so forth, which is also summarised in appendix A. However, the actual amount paid by companies also depends on available tax deductions. Many countries allow companies to carry forward losses, i.e. where losses in one year can be used to offset future taxes. Therefore, in order to give a more correct and comparable assessment of tax level, studies have been done that compare aggregate tax level throughout the lifetime of a standardised model-mine with the same physical properties and same production method, but in different jurisdictions. Currently, there are no such studies available that cover all the Nordic countries. From those that exist, however, it is possible to draw some conclusions, especially considering that the Nordic tax levels, with the possible exception of Greenland, are on a more or less comparable level.

The most cited attempt to measure effective tax is based on a copper mine financial model built by James Otto, inter alia published in a 2006 World Bank report. Here, effective tax is equal to the value of all amounts paid to government divided by the value of profits before taxes are paid. Greenland and Sweden are included in a review along with twenty other countries. The results show that Sweden was ranked as having the lowest effective tax rate at the time, at $28.6 \%$. Greenland, on the other hand, had a much higher level estimated at $50.2 \%$. The median was $46.3 \% .{ }^{82}$

Tax reforms should yield revisions of the effective tax levels. This includes e.g. a reduction in Swedish corporate tax levels from 28 to 22\% since 2008, and from 26 to 20\% in Finland since 2011. More recently PricewaterhouseCoopers (PwC) has also looked at government take of profits of a model mining projects. Estimates have been done for the development and production of a model mine over a given period of

82 Otto, James et al. (2006). Mining Royalties: A Global Study of Their Impact on Investors, Government, and Civil Society. Washington DC: World Bank, 265. 
time. In a 2012 publication from Goldman Sachs, PwC estimates for a model copper mine includes Finland and Sweden. Their respective government take of profits is 25 and $22 \%$, which is the lowest rate among the ten countries included in the survey. The median was $31.5 \%$.

Appendices to the Greenland Oil and Mineral Strategy present PwC estimates for the effective tax rate on a model gold and model iron project in ten jurisdictions, including Greenland and Sweden. Sweden is ranked as having the lowest government take of all tax regimes compared, at $22.2 \%$ and $23.2 \%$ for the gold and iron projects respectively. The rates in Greenland are $37.3 \%$ and $38.4 \%$, slightly below the median of the countries included in both cases, which stands at $37.9 \%$ and $40.5 \%$. Notably the study does not account for the effects of import taxes, VAT or possible tax deductions.

Lastly, other studies have also looked at mineral taxation in different jurisdictions, but have not attempted to calculate an effective tax rate. One of the reports notes that a relatively unique aspect of taxation in the Nordic countries is that royalty is paid to the landowner, even though the state holds the right to issue permits for the exploitation of minerals. This system can be found in Finland, Norway and Sweden. ${ }^{83}$ The table in appendix A of this report includes information on the main fees and taxes to be paid by the mining industry in the Nordic countries.

Figure 2: Effective tax rate studies (government take in percent of total)

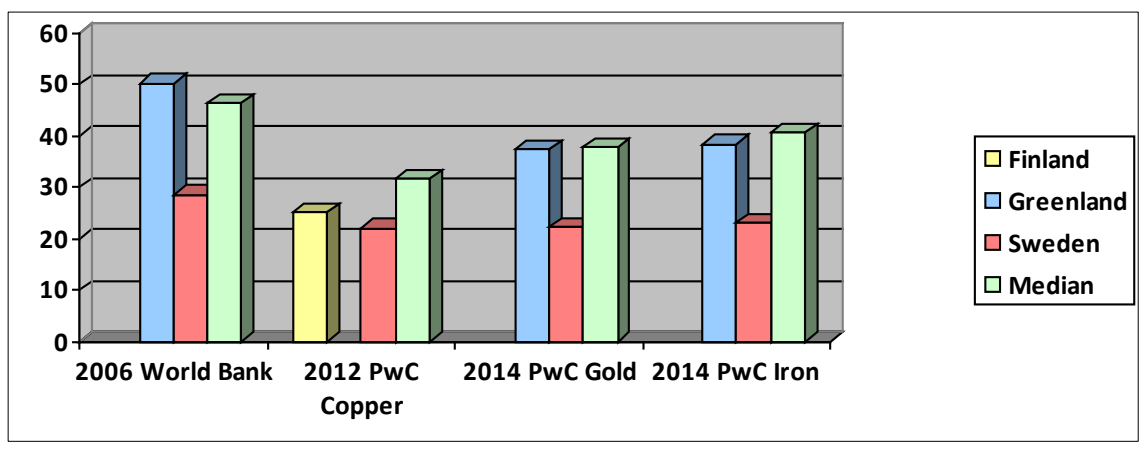

Source: Otto et al. 2006; PwC 2012.

${ }^{83}$ Ericsson, Magnus \& Farooki, Masuma (2012). Taxation in the Mining Sector - Selected Case Studies. Stockholm: Raw Materials Group. 
While Denmark, Iceland and Norway have not been included in the above-mentioned estimates of effective tax regimes, it can be assumed that they are closer to Finnish and Swedish levels due to similarities such as the generally low levels of mineral royalties and overall comparable corporate tax levels. At the same time, the studies do not consider e.g. taxes paid by employees, which indirectly affect company total costs and payments to government.

The overall investor-friendliness of the Nordic mining taxation regime is confirmed by surveys. In the Fraser Institute Annual Survey of Mining Companies from 2013, respondents are asked for their perception whether taxation regimes in different countries encourage or deter investment. "Taxation regime" includes personal, corporate, payroll, capital and other taxes, as well as complexity of tax compliance. The Nordic jurisdictions included all rank among the ten jurisdictions which respondents most frequently consider to have an investment-encouraging taxation regime. However, while respondents are very unanimous in their praise of Sweden and Finland, Norway and Greenland receive somewhat more mixed reviews. This is illustrated in the table below.

\begin{tabular}{|c|c|c|c|c|c|}
\hline Response & 1 & 2 & 3 & 4 & 5 \\
\hline Finland & $31 \%$ & $51 \%$ & $14 \%$ & $4 \%$ & $0 \%$ \\
\hline Greenland & $36 \%$ & $36 \%$ & $14 \%$ & $14 \%$ & $0 \%$ \\
\hline Norway & $23 \%$ & $43 \%$ & $23 \%$ & $10 \%$ & $0 \%$ \\
\hline Sweden & $32 \%$ & $50 \%$ & $16 \%$ & $2 \%$ & $0 \%$ \\
\hline
\end{tabular}

1: Encourages investment

2: Not a deterrent to investment

3: Mild deterrent to investment

4: Strong deterrent to investment

5: Would not pursue investment due to this factor

Source: Fraser Institute Annual Survey of Mining Companies 2013.

Another way to measure the effective tax rate is doing so ex post. In other words, by looking at what mining companies have actually had to pay. For example, companies that comply with the Global Reporting Initiative (GRI) are obliged to provide information on payments to governments. In the Nordic countries, 8 out of 21 surveyed companies that operate mines apply a version of GRI. The ones that do so, tend to be among the bigger mining companies in the region. However, it is difficult to compare their payments to government with turnover and profits as they in many cases report only the total of all payments to all governments, and not for a specific mine operation. And while this may give an indication of the tax level 
in a country where there is an active mining industry, it is obviously of less guidance for countries which are not yet but may become large mineral producers. An obvious example here is Greenland.

Overall, the Nordic countries seem to be characterised by having among the lowest tax rates for any mining region. Discussions on why the Nordic countries have decided to pursue a relatively low-tax strategy, is outside of the scope of this report. Furthermore, what level of taxation is ultimately sustainable will, obviously, be subject to differing views. For example, some could argue that a higher tax level, or in other words, a lower rate of return for investors, could be tolerated in a stable jurisdiction. Conversely, higher risk should be associated with greater reward. ${ }^{84}$ On the other hand, others have argued that tougher demands, such as stringent environmental jurisdiction, motivate a lower tax rate. ${ }^{85}$

The following country-specific reviews focuses on taxation according to mining and mineral laws. In particular, focus will be on mineral royalties. Administrative fees for licence applications will not be covered here. They are, however, included in the table in appendix A.

\subsection{Denmark}

A number of minerals are taxed in Denmark according to the Act on Taxation of Waste and Raw Materials of 2011. This applies both to extraction in Denmark and import. The list of raw materials covered by the Act is listed in an annex, and it covers all materials explicitly mentioned in the Raw Materials Act. The tax is DKK 5 per cubic metre of material.

According to the Raw Materials Act, there is no tax or fee for exploitation on land, and nor is there for licences to explore the seabed and continental shelf. However, security is needed for clean-up and rehabilitation. Section 22 a. of the Act presents compensations for the exploitation of raw materials underwater. Notably, for common areas, licence holders shall generally pay DKK 8 per cubic metre of material. This can be reduced to DKK 6 if the licence holder has paid for exploration and EIA for the area in question. For areas granted according to an auction, however, the licence holder shall pay DKK 25,000 per 100 hectare of area to

\footnotetext{
84 Mitchell, Paul (2009). Taxation and investment issues in mining. Oslo: EITI, 27-31.

${ }^{85}$ See e.g. http://www.dn.se/debatt/hoga-miljokrav-pa-gruvor-motiverar-lag-mineralavgift/
} 
which he or she has exclusive rights, and a minimum of DKK 2.50 for each square metre of extracted raw materials.

Finally, the Act on the Use of the Danish Subsoil of 2011 regulates salt exploitation in Denmark. The Ministry of Climate, Energy and Building decides on the royalty to be paid by a licence holder according to the Act section 9. Today, salt exploitation is only done by one company, Akzo Nobel Salt A/S. According to their licence, they shall pay DKK 9.51 per ton salt, subject to revision every three years to reflect price development. In 2013, this amounted to a total of DKK 6.2 M in royalties to the Danish state.

\subsection{Finland}

According to the new Mining Act of 2011, mining permit holders must pay owners of properties covered by the mine area EUR 50 per hectare. Additionally, in the case of metal ore mines, the landowner shall receive 1.5 per mille of the value of the minerals mined. However, as there are no mines in operation that have been permitted under the new Mining Act, current compensations follow the old Mining Act of 1965. Under the old Act, landowners and mining companies could negotiate proper compensations. If agreement was reached, they did not have to report on the level of compensation. In a very few cases, where agreements could not be reached, the responsible Ministry decided on compensations following recommendation from the mining council. ${ }^{86}$

Following a law from 1940 on the Government's right to divest itself of state-owned mineral deposits and their exploitation and thereto required land, the Finnish state receives extra royalties from certain mines. In the government budget for 2015, this royalty is expected to amount to EUR 3 M. Finally, as in other Nordic countries, the Finnish mining industry is subject to a number of other taxes. This also includes environmental taxes. While a full overview of these will not be provided here, it is worth noting that from 2015 onwards, the mining industry will no longer have a right to a reduced electricity tax. This is expected to increase tax income to the government by EUR $20 \mathrm{M}$.

\footnotetext{
86 Personal communication with Riikka Aaltonen, Ministry of Employment and the Economy, Finland, 2015-02-06
} 


\subsection{Greenland}

Section 17-1 of the Mineral Resources Act of Greenland states that " $[t]$ he amount to be paid by the licensee to the Greenland Self-Government is laid down in a licence [...]". Royalties are set out in a separate document, approved by the Government of Greenland together with application procedures and standard terms for exploration and prospecting licences for minerals. Royalty rates are different for different minerals, and presented in an addendum to the standard terms. Notably, the normal royalty rate is $2.5 \%$ of the sales value of minerals. For rare earth elements and uranium, the rate is $5 \%$. And finally, for gemstones the sales royalty rate is $5.5 \%$, and additionally, a surplus royalty of $15 \%$ is payable based on gross profit exceeding $40 \%$.

Furthermore, the document notes that deviations from the standard terms may be used. Another notable provision can be found in the Mineral Resources Act section 17-2. Accordingly, a licence "may prescribe that a company controlled by the Greenland Self-Government will be entitled on specified terms to join as a participant in the activities covered by the licence".

In addition to these taxes, mining companies may be required to reach an Impact Benefit Agreement (IBA) with the Greenland Government. According to guidelines from the Bureau of Minerals and Petroleum, the IBA "consists of two parts: Firstly, it shall define the terms that are expected to be valid throughout the lifespan of the project. Secondly, the IBA shall define more specific targets and plans for implementing the IBA successfully". ${ }^{87}$ Agreements shall include provisions on, inter alia, employment policy and commitments; human resource development including education targets for Greenlandic workforce; business development, e.g. quantitative targets for involvement of Greenlandic companies; social well-being and cultural initiatives for staff and community; monitoring and dispute resolution. Needless to say, it is difficult to estimate what costs such agreements might lead to for companies.

\footnotetext{
${ }^{87}$ Bureau of Minerals and Petroleum, (2009). Guidelines for Social Impact Assessments for mining projects in Greenland, 13.
} 


\subsection{Iceland}

In Iceland, there is no statutory level of minerals compensation. Holders of utilisation licences for minerals on somebody else's property are obliged to reach an agreement with the landowner on compensation for the resources. If an agreement cannot be reached, the Minister of Industry may expropriate the necessary land, at the expense of the licence holder. With regards to state-owned land, the Minister of Industry may negotiate with utilisation licence holders on remuneration after consulting with the party administering the property. The latter is done according to the Public Land Act.

As noted earlier, the Act on the Survey and Utilisation of Ground Resources covers resources in the ground on land, at the bottom of rivers and lakes, and at the bottom of the sea within 115 metres from the shore, at a depth of 115 metres maximum. While the Act does not specify any royalty to be paid by licence holders, section $18 \mathrm{~A}$ states, inter alia, that "[a] prospecting and/or utilisation licence shall specify [...] [p] urchase of insurance for any potential liability of the licence holder for damages; Monitoring and payment of cost of monitoring; Payment of licence fee to meet the cost of the preparation and issue of the licence $[\ldots]$.. In other words, provisions on administration fees and monitoring costs are to be included in the permit.

Exploitation of seabed resources beyond areas covered above, is permitted by the National Energy Agency through the Act on the Ownership of the Icelandic State of the Resources of the Sea Floor. Section 3 of the latter states that the National Energy Agency may negotiate payments for the exploitation of seabed resources. Income thereof shall usually be used to support research on the seabed and continental shelf. Regulations issued pursuant to the Act provide more detailed information on the procedure regarding decisions on compensation. Finally, according to the Act, the licence shall specify payments to cover monitoring costs.

\subsection{Norway}

The Norwegian Minerals Act and pursuant regulations stipulate fees to be paid for exploration and exploitation of state-owned minerals, including for pilot extraction, operating licence and compulsory acquisition. The state primarily receives compensation for minerals calculated on the basis of the area covered by the exploration or exploitation permit. The landowner shall normally receive $0.5 \%$ of the sales value of minerals. In Finnmark, this is increased to $0.75 \%$. 
Like in other Nordic countries, a number of other taxes are also of importance for the mining industry. One notable tax in Norway is the municipal property tax. It is voluntary for municipalities to adopt the tax, and they enjoy a certain degree of freedom in design. It may cover all real estate in the municipality, or be limited to business premises. Annual tax levels may vary between 0.2 and $0.7 \%$ of the taxable fiscal value of the property. Calculations of property value is therefore of importance for subsequent taxation. Notably, two of the three companies currently operating metal mines in Norway have been involved in court trials together with their host municipalities on this issue. 88

\subsection{Sweden}

A revision of the Swedish Minerals Act in 2005 saw the introduction of a mineral compensation fee equal to 2 per mille of average value of the concession minerals mined. Of this 1.5 per mille is due to the landowner, and 0.5 per mille to the state. The fee however only applied to new mines, and not to those already in operation.

In 2013, mineral compensation fees totalled SEK 6.9 M in 2013, of which SEK 1.7 M went to the state and SEK $5.2 \mathrm{M}$ to landowners. In addition, the state received SEK 17.9 M in various fees following the Minerals Act, such as fees for applications, exploration, permit extensions and designation of land. In the same period, the mining industry had a turnover of SEK $37.3 \mathrm{bn}$, and taxes and fees amounted to SEK $1.7 \mathrm{bn}$. However, Sweden is a special case as the most profitable mining company in recent years is the state-owned iron ore producer LKAB. The company paid a dividend of SEK $3.5 \mathrm{bn}$. This can be compared to SEK $0.5 \mathrm{bn}$ in dividends to private investors and owners paid by the rest of the sector. ${ }^{89}$

Similarly to Denmark, Sweden taxes natural gravel exploitation. The objective, according to the Swedish Tax Agency, is to improve management of finite resources. The tax is currently set at SEK 13 per ton. Landowner exploitation for private use is exempted.

${ }^{88}$ http://www.nrk.no/troms/sor-varanger-vant-i-hoyestrett-1.7480222; http://www.highnorthnews.com/nekter-a-la-jernmalm-takseres-som-naturgrus-anker-til-lagmannsretten/ 89 Geological Survey of Sweden (2014). Bergverksstatistik 2013. Statistics of the Swedish Mining Industry 2013. Uppsala: Geological Survey of Sweden; http://www.sgu.se/om-sgu/nyheter/2015/februari/ gruvnaringens-omsattning-sjonk-kraftigt/ 


\section{Discussion}

The earlier review of the legal frameworks for mining activities in the Nordic countries has shown that there are a lot of similarities. Especially Finland, Norway and Sweden are comparable, not just with regards to legal situation, but also climate, geology and social context. Not least due to influence from the EU, environmental legislation throughout the Nordic region is comparable. However, differences exist. One regards how stakeholders such as the Sami people or municipalities are included in the process, where Norway seems to have given these a larger say than Finland and Sweden have. Denmark and Iceland do not have as developed a framework for mining as their Nordic peers, for understandable reasons.

Of all the jurisdictions compared, Greenland is the most obvious outlier. For example, Greenland is alone in demanding that companies perform SIAs and sign IBAs. Of course, even in countries that only require an EIA, SIAs are sometimes conducted anyway. Research on the development in Sweden indicates that the reason for the more ambitious EIAs and SIAs may be influence from international trends. This may also be the reason why SIAs seem to be more common in Finland than in Sweden, as the Finnish mining sector is more dominated by international companies than the latter. Overall though, it seems fair to conclude that legislation around social issues seems to be less developed than economic and environmental aspects, not least with regards to company reporting requirements.

It is important to note that this review has been limited to looking at relevant laws and what provisions they contain, with particular focus on mining and mineral laws. However, a deeper legal comparison would look more closely at how the law has been interpreted and how it has played out in practice. Not least would this be of importance to judge how different laws interact, e.g. mineral and planning laws.

The level of taxation on mining activities is also difficult to establish as it depends on a range of factors: in addition to fees and royalties, a range of other taxes and tax deductions exist. Ideally, comparing level of taxation for the same mine in different jurisdictions requires extensive modelling. Existing studies and stated tax levels indicate similarities here as well: Norwegian tax levels seem to be somewhat higher than in 
Finland and Sweden, which in turn rank among having the lowest taxes on mining companies in the world in other studies. In Denmark and Iceland, fees for exploitation licences according to the Subsoil Act and Act on the Survey and Utilisation of Ground Resources, are subject to negotiations, so it is difficult to compare. Again, Greenland is an outlier compared to its Nordic neighbours, with higher but varying levels of royalty, a higher level of corporate tax, but no VAT.

The differences between the Nordic countries may be due to several reasons. Historical and political circumstances arguably play an important role. The more extensive rights held by Samis in Norway are often ascribed to past controversies around natural resource exploitation in the north, more precisely the building of a hydroelectric power plant in Alta. And so, considering much-publicised problems surrounding some mining companies in the last few years, as well as possible events in the years to come, it only seems predictable that we can expect more legal revisions ahead. 


\section{References}

Aaro, Lars-Eric, Ferbe, Anders, Evrell, Lennart, Fahlberg, Cecilia, Sundelin, Bengt, Sterte, Johan, Waplan, Karl-Axel, Bennerdt, Staffan, Bengtsson, Ulf, Hedlin, Johan, Gustavsson, Lennart \& Ahl, Per (2012). Ge gruvorna chansen. Stockholm: Dagens Industri.

Abrahamsson, Lena, Segerstedt, Eugenia, Nygren, Magnus, Johansson, Jan, Johansson, Bo, Edman, Ida \& Åkerlund, Amanda (2014). Gender, Diversity and Work Conditions in Mining. Luleå: Luleå University of Technology.

Arbejdsgruppen om konsekvenserne af ophævelse af nul-tolerancepolitikken (2013). Rapport om udvinding og eksport af uran.

Bureau of Minerals and Petroleum. (2009). Guidelines for Social Impact Assessments for mining projects in Greenland. Nuuk: Bureau of Minerals and Petroleum.

Bäckström, Lars (2012). Rätten till mineral: en studie om befogenheter och legala inskränkningar i äganderätten till fastighetens beståndsdelar. Luleå: Luleå University of Technology.

Committee for Greenlandic Mineral Resources to the Benefit of Society. (2014). For the benefit of Greenland. Nuuk: University of Greenland.

Danish Energy Agency (2010). Redegørelse efter $\$ 6$ i undergrundsloven om en ny tilladelse til indvinding af salt ved opskylning til Akzo Nobel Salt A/S. Copenhagen: Danish Energy Agency.

Danish Energy Agency (2014). Oil and Gas Production in Denmark 2013 and Subsoil Use. Copenhagen: Danish Energy Agency.

Danish Environment Agency (2011). Overblik over råstofindvinding - hvor og hvordan søges tilladelse. Copenhagen: Danish Environment Agency.

Danish Environment Agency (2007). Råstofinvdindning på land. Drejebog for VVM. Copenhagen: Danish Environment Agency.

Elgstrand, Kaj \& Vingärd, Eva (eds.) (2013). Occupational Safety and Health in Mining: Anthology on the Situation in 16 Mining Countries. Gothenburg: University of Gothenburg.

Ericsson, Magnus \& Farooki, Masuma (2012). Taxation in the Mining Sector-Selected Case Studies. Stockholm: Raw Materials Group.

Fraser Institute (2015). Fraser Institute Annual Survey of Mining Companies 2014. Vancouver: Fraser Institute.

Fraser Institute (2014). Fraser Institute Annual Survey of Mining Companies 2013, Vancouver: Fraser Institute.

Fredricsson, Christian \& Sma, Lukas (2013). En granskning av Norges planeringssystem. Skandinavisk detaljplanering i ett internationellt perspektiv. Nordregio report 2013:1. Stockholm: Nordregio.

Geological Survey of Sweden (2014). Bergverksstatistik 2013. Statistics of the Swedish Mining Industry 2013. Uppsala: Geological Survey of Sweden.

Geological Survey of Sweden (2013). Vägledning för prövning av gruvverksamhet. Uppsala: Geological Survey of Sweden. 
Georange (2011). Georanges vägledning för samråd \& dialog. Malå: Georange.

Government of Finland (2009). Regeringens proposition till Riksdagen med förslag till gruvlag och vissa lagar som har samband med den, RP 273/2009 rd. Helsinki: Government of Finland.

Government of Greenland (2014). Greenland's oil and mineral strategy 2014-2018. Nuuk: Government of Greenland.

Hardardóttir, Vigdís (2011). Metal-rich Scales in the Reykjanes Geothermal System, SW Iceland: Sulfide Minerals in a Seawater-dominated Hydrothermal Environment. Ottawa: University of Ottawa.

Johansson, Bo \& Johansson, Jan (2008). Work environment and work organization in the Swedish and Finnish mining industry. Luleå: Luleå University of Technology.

Kauppila, Päivi, Räisänen, Marja Liisa \& Myllyoja, Sari (2011). Best environmental Practices in Metal Ore Mining. Helsinki: Finnish Environment Institute.

Koivurova, Timo \& Petrétei, Anna (2014). Enacting a New Mining Act in Finland How were Sami Rights and Interests Taken into Account? Nordic Environmental Law Journal 1.

Kokko, Kai, Oksanen, Anniina, Hast, Sanna, Heikkinen, Hannu I., Hentilä, Helka-Liisa, Jokinen, Mikko, Komu, Teresa, Kunnari, Marika, Lépy, Élise, Soudunsaari, Leena, Suikkanen, Asko \& Suopajärvi, Leena (2014). Sound mining in the North: a guide to environmental regulation and best practices supporting social sustainability.

Liedholm Johnson, Eva (2010). Mineral rights: Legal systems governing exploration and exploitation. Stockholm: Royal Institute of Technology.

Ministry of Employment and the Economy (2004). Guide. Exploration in protected areas, the Sámi homeland and the reindeer managing area. Helsinki: Ministry of Employment and the Economy.

Ministry of Employment and the Economy (2011). New Mining Act to enter into force on 1 July. Helsinki: Ministry of Employment and the Economy.

Ministry of Trade and Industry (2009). Ot.prp. nr. 43 (2008-2009). Om lov om erverv og utvinning av mineralressurser (mineralloven). Oslo: Ministry of Trade and Industry.

Ministry of Trade and Industry (2011). Veileder til mineralloven. Oslo: Ministry of Trade and Industry.

Ministry of Trade and Industry (2013). Strategy for the Mineral Industry. Oslo: Ministry of Trade and Industry.

Mitchell, Paul (2009). Taxation and investment issues in mining. Oslo: EITI.

Nordic Council of Ministers (2011). Comparative study of legislation and legal practices in the Nordic countries concerning labour inspection. Copenhagen: Nordic Council of Ministers.

Otto, James, Andrews, Craig, Cawood, Fred, Doggett, Michael, Guj, Pietro, Stermole, Frank, Stermole, John \& Tilton, John (2006). Mining Royalties: A Global Study of Their Impact on Investors, Government, and Civil Society. Washington DC: World Bank. http://dx.doi.org/10.1596/978-0-8213-6502-1

Pettersson, Maria, Oksanen, Anniina, Masloboev, Vladimir, Mingaleva, Tatiana \& Petrov, Victor (2015). License to Mine: a comparison of the scope of the environmental assessment in Sweden, Finland and Russia. Natural Resources 6. http://dx.doi.org/10.4236/nr.2015.64022

PwC (2012). Corporate income taxes, mining royalties and other mining taxes. A summary of rates and rules in selected countries. London: PwC.

Ranängen, Helena (2013). Corporate Social Responsibility Practice in the Mining Industry. Luleå: Luleå University of Technology. 
Scannell, Yvonne (2012). The Regulation of Mining and Mining Waste in the European Union. Washington and Lee Journal of Energy, Climate, and the Environment 177.

Shooks, Malin, Johansson, Bo, Andersson, Eira \& Lööw, Joel (2014). Safety and Health in European Mining: A report on safety and health, statistics, tools and laws, produced for the I2Mine (Innovative Technologies and Concepts for the Intelligent Deep Mine of the Future) project. Luleå: Luleå University of Technology.

Swedish Society for Nature Conservation (2013). Credibility at Stake - How FSC Sweden Fails to Safeguard Forest Biodiversity. Stockholm: Swedish Society for Nature Conservation.

Söderholm, Patrik \& Svahn, Nanna (2014). Mining, Regional Development and Benefit-Sharing. Luleå: Luleå University of Technology.

Tarras-Wahlberg, Håkan (2014). Social license to mine in Sweden: do companies go the extra mile to gain community acceptance? Mineral Economics 27.2-3.

U.S. Geological Survey (2014). 2012 Minerals Yearbook. Denmark, the Faroe Islands, and Greenland. Reston, VA: USGS.

U.S. Geological Survey (2014). 2012 Minerals Yearbook. Iceland. Reston, VA: USGS.

Wagner, Horst et al. (2004). Minerals planning policies and supply practices in Europe, Leoben: Montanuniversität Leoben.

Widerlund, Anders, Öhlander, Björn \& Ecke, Frauke (2014). Environmental Aspects of Mining. Luleå: Luleå University of Technology.

Williams, John P. (2012). Global trends and tribulations in mining regulation. Journal of Energy \& Natural Resources Law 30. 



\section{Sammanfattning}

Under de senare åren har det varit stor aktivitet inom den nordiska gruvindustrin. Nya gruvor har öppnats, men branschen har även drabbats av konkurser. Ökad aktivitet har i sin tur föranlett diskussioner kring hur lagstiftning och skatter kan säkerställa att gruvbrytning bidrar till en hållbar utveckling. Samtidigt har ett flertal frivilliga hållbarhetsinitiativ utvecklats. Syftet med denna rapport är att ge en översikt över lagstiftning och skatter för gruvindustrin i Norden.

Av historiska skäl finns stora likheter mellan de nordiska ländernas lagar. Inte minst när det gäller miljölagstiftning har EU bidragit till harmonisering, även på Island och i Norge. Samtidigt finns påtagliga olikheter. Ibland sker lagändringar som följd av omdiskuterade problem, med den konsekvensen att händelser och erfarenheter i varje enskilt land spelar en viktig roll. Till exempel har den samiska befolkningen och kommuner fått ett större inflytande i Norge. Enligt den finska gruvlagen är gruvsäkerhetstillstånd obligatoriskt. I Danmark och Island reflekterar lagstiftningen det faktum att båda har en relativt liten mineralindustri. Mest säreget är kanske Grönland. Till exempel skiljer inte lagen mellan mineraler som tillfaller jordägaren och de som tillfaller staten. Dessutom är både social- och miljökonsekvensbeskrivningar obligatoriska, till skillnad för i övriga nordiska länder.

En översikt av skatter visar även på likheter och skillnader: Finland och Sverige anses ha bland världens lägsta effektiva beskattning av gruvdrift, medan nivån i Norge är något högre. Också här utmärker Grönland sig med en hög ersättningsnivå för mineraler i ett nordiskt sammanhang. Den grönländska nivån är dock mer jämförbar med den globala medianen. Samtidigt måste jämförelserna tolkas med varsamhet, eftersom ett flertal andra skatter samt möjliga avdrag spelar en viktig roll för det faktiska skatteuttaget. 



\section{Appendix A. Taxation table}

\begin{tabular}{|c|c|c|c|c|c|c|}
\hline & Denmark & Finland & Greenland & Iceland & Norway & Sweden \\
\hline \multicolumn{7}{|l|}{ Background information } \\
\hline $\begin{array}{l}\text { Number of active metallic } \\
\text { mines } 2013\end{array}$ & 0 & 12 & 0 & 0 & $3^{90}$ & 16 \\
\hline $\begin{array}{l}\text { Directly employed by mining } \\
\text { companies } 2013\end{array}$ & $\begin{array}{l}\text { 2012: } 2,200 \text { in industrial } \\
\text { minerals }\end{array}$ & $\begin{array}{l}3,400 \text { including industrial } \\
\text { minerals }\end{array}$ & $\begin{array}{l}128 \text { in minerals and } \\
\text { hydrocarbons industries }\end{array}$ & $\begin{array}{l}100 \text { in mining and quarry- } \\
\text { ing }\end{array}$ & $\begin{array}{l}\text { 1,295 in metal mining, } \\
6,226 \text { for all minerals }\end{array}$ & $\begin{array}{l}6,295 \text { excluding industrial } \\
\text { minerals }\end{array}$ \\
\hline Turnover 2013 & $\begin{array}{l}\text { Gravel and stone: } \\
\text { DKK } 2.5 \text { bn }\end{array}$ & $\begin{array}{l}\text { EUR } 1.5 \text { bn including } \\
\text { industrial minerals }\end{array}$ & $\begin{array}{l}\text { 2012: DKK } 89 \text { M including } \\
\text { hydrocarbons }\end{array}$ & $\begin{array}{l}\text { ISK } 3.9 \text { bn in mining and } \\
\text { quarrying }\end{array}$ & $\begin{array}{l}\text { NOK } 13 \text { bn total minerals } \\
\text { industry }\end{array}$ & $\begin{array}{l}\text { SEK } 33 \text { bn excluding } \\
\text { industrial minerals }\end{array}$ \\
\hline Prospecting licences granted 2013 & $n / a$ & $n / a$ & 22 & $\mathrm{n} / \mathrm{a}$ & n/a & $\mathrm{n} / \mathrm{a}$ \\
\hline Exploration licences granted 2013 & $3^{91}$ & 110 & 76 & $0^{92}$ & 162 & $113^{93}$ \\
\hline Exploitation/mining licences 2013 & $11^{102}$ & 32 & 5 & 0 & 6 & 5 \\
\hline Other licences granted 2013 & & & $\begin{array}{l}\text { Prospecting: } 22 \\
\text { Small-scale: } 12\end{array}$ & & & \\
\hline $\begin{array}{l}\text { Ranking Fraser Policy Perception Index } \\
2013 \text { (of 112) }\end{array}$ & n/a & 2 & 23 & n/a & 10 & 1 \\
\hline Mining association requirements & & & Ethical rules ${ }^{94}$ & & Ethical rules & Ethical rules \\
\hline
\end{tabular}

${ }^{90}$ Additionally, 4 coal mines on Svalbard, of which one is under Russian ownership and jurisdiction.

${ }^{91}$ Number of licences for seabed resources granted through auctions according to section 20 of the Raw Materials Act.

${ }^{2}$ No new licences granted in 2013. There is currently one valid licence for prospecting and exploration, which focuses on gold in nine different areas.

${ }_{93}$ Additionally, 158 mineral exploration licences were prolonged. Excludes hydrocarbons and diamonds.

${ }^{94}$ Employers' Association of Greenland. Mining-specific association does not exist. 


\begin{tabular}{|c|c|c|c|c|c|c|}
\hline & Denmark & Finland & Greenland & Iceland & Norway & Sweden \\
\hline \multicolumn{7}{|l|}{ Mineral-specific fees and taxes } \\
\hline & & & $\begin{array}{l}\text { (According to standard } \\
\text { terms) }\end{array}$ & & (Svalbard not included) & \\
\hline Exploration permit application fee & 0 & $\begin{array}{l}<1,000 \text { ha: } \\
\text { EUR } 3,000 . \\
1001-2,000 \text { ha: } \\
\text { EUR } 6,000 . \\
2001-4,000 \text { ha: EUR } 8,000 . \\
>4,000 \text { ha: } \\
\text { EUR } 10,000 .\end{array}$ & DKK 5,000 & 0 & NOK 1,000 & $\begin{array}{l}\text { SEK } 500 \text { per } 2,000 \text { hec- } \\
\text { tares }\end{array}$ \\
\hline Exploration permit fee & 0 & $\begin{array}{l}\text { Annual sum per hectare } \\
\text { per year to landowner: } \\
\text { Years 1-4: EUR 20. Years } \\
\text { 5-7: EUR 30. Years } \\
\text { 8-10: EUR 40. Years 11- } \\
\text { 15: EUR } 50\end{array}$ & $\begin{array}{l}\text { To government Years 1-5: } \\
\text { DKK } 34,700 \text {. Years 6-10: } \\
\text { DKK } 34,700 \text {. Years } 11-13 \text { : } \\
\text { DKK } 34,700 \text {. Years: } 14-16 \text { : } \\
\text { DKK } 34,700+\text { annual fee } \\
\text { from year } 6 \text { onwards: DKK } \\
39,700\end{array}$ & $\begin{array}{l}\text { To government: ISK } \\
160,000\end{array}$ & $\begin{array}{l}\text { Annual sum per hectare } \\
\text { per year to government: } \\
\text { Years 2-3: NOK } 10 \text {. Years } \\
4-5 \text { : NOK 30. Years } \\
6-7 \text { : NOK } 50 . \text { Extension } \\
\text { beyond year 7: NOK } 50\end{array}$ & $\begin{array}{l}\text { Annual sum per hectare to } \\
\text { government: SEK } 20 \\
\text { covering first three years. If } \\
\text { permit extended: SEK } 21 \\
\text { annually years } 4-6 \text {, } \\
\text { SEK } 50 \text { annually years } \\
7-10 \text {, SEK } 100 \text { annually } \\
\text { years } 11-15\end{array}$ \\
\hline Exploitation permit application fee & 0 & EUR 5,000 & DKK 100,000 & 0 & $\begin{array}{l}\text { NOK 10,000. NOK } 500 \\
\text { extra per additional area }\end{array}$ & SEK 80,000 \\
\hline Mineral tax level & $\begin{array}{l}\text { For seabed resources } \\
\text { according to Raw Materi- } \\
\text { als Act: Exclusive permit } \\
\text { area: DKK } 25,000 \text { annually } \\
\text { per } 100 \text { hectares + mini- } \\
\text { mum DKK } 2.50 \text { per cubic } \\
\text { metre extracted material. } \\
\text { Non-exclusive area: DKK } 8 \\
\text { per cubic metre extracted } \\
\text { material. DKK } 6 \text { per cubic } \\
\text { metre for operator who } \\
\text { has paid for exploration } \\
\text { and EIA. }{ }^{95} \text { According to } \\
\text { Subsoil Act: Based on } \\
\text { agreement }\end{array}$ & $\begin{array}{l}\text { For metallic minerals: EUR } \\
50 \text { per hectare area to } \\
\text { landowner annually + } \\
0.15 \% \text { of value. Additional } \\
\text { for other minerals: accord- } \\
\text { ing to agreement or mining } \\
\text { authority decision. Addi- } \\
\text { tional for by-products: } \\
\text { according to agreement or } \\
\text { max } 10 \% \text { of sales pro- } \\
\text { ceeds. Gold panning: EUR } \\
50 \text { per hectare to institu- } \\
\text { tion responsible for } \\
\text { management of area }\end{array}$ & $\begin{array}{l}\text { Sales royalty of } 2.5 \% \text { of the } \\
\text { value of the minerals to } \\
\text { the Government of Green- } \\
\text { land. } 5 \% \text { for rare earth } \\
\text { elements and uranium. } \\
5.5 \% \text { for gemstones. } \\
\text { Additional } 15 \% \text { surplus } \\
\text { royalty on gross profit } \\
\text { exceeding } 40 \%\end{array}$ & $\begin{array}{l}\text { Compensation to land- } \\
\text { owner according to } \\
\text { agreement. }\end{array}$ & $\begin{array}{l}\text { For state-owned minerals: } \\
\text { NOK } 100 \text { per hectare per } \\
\text { year to the government. } \\
0.5 \% \text { of sales value to the } \\
\text { landowner. } 0.75 \% \text { in case } \\
\text { of exploitation on land } \\
\text { owned by Finnmarks- } \\
\text { eiendommen }\end{array}$ & $\begin{array}{l}\text { For concession minerals: } \\
0.15 \% \text { of value of minerals } \\
\text { to landowner, } 0.05 \% \text { to } \\
\text { the government }\end{array}$ \\
\hline
\end{tabular}

95 Taxes according to the Raw Materials Act are indexed. For example, in 2015, permits for exclusive areas are subject to fee of DKK 26,785 per 100 hectares + minumum of DKK 2.68 per cubic metre of extracted material. 


\begin{tabular}{|c|c|c|c|c|c|c|}
\hline & Denmark & Finland & Greenland & Iceland & Norway & Sweden \\
\hline \multicolumn{7}{|l|}{ Taxation } \\
\hline Other fees & $\begin{array}{l}\text { Waste and raw materials } \\
\text { tax: DKK } 5 \text { per cubic metre } \\
\text { (in addition to mineral tax } \\
\text { below) }\end{array}$ & $\begin{array}{l}\text { For all permit application } \\
\text { fees: EUR } 95 \text { per hour } \\
\text { administration. } \\
\text { Reservation fee, area } \\
<10,000 \text { hectares: EUR } \\
1,200 .>10,000 \text { hectares: } \\
\text { EUR } 2,200 \text {. } \\
\text { Gold panning application } \\
\text { fee: EUR } 700\end{array}$ & $\begin{array}{l}\text { Prospecting permit fee: } \\
\text { DKK } 3,000 \text { + DKK } 23800 \\
\text { upon granting. } \\
\text { Exploitation: Small scale, } \\
\text { non-exlusive: DKK } 500 . \\
\text { Small-scale, exclusive: } \\
\text { DKK } 1,000\end{array}$ & & $\begin{array}{l}\text { Pilot extraction permit: } \\
\text { NOK } 5,000 \text {. } \\
\text { Operating licence: } \\
\text { NOK } 10,000 / 20,000 .^{96} \\
\text { Compulsory acquisition: } \\
\text { NOK } 1,000 / 10,000^{97}\end{array}$ & $\begin{array}{l}\text { Land designation fee: } \\
\text { SEK } 40,000 / 80,000^{98}\end{array}$ \\
\hline \multicolumn{7}{|l|}{ General taxes } \\
\hline Corporate tax & $24.5 \%^{99}$ & $20 \%$ & $30 \% / 31.8 \%^{100}$ & $20 \%$ & $27 \%^{101}$ & $22 \%$ \\
\hline VAT & $25 \%$ & $24 \%$ & $0 \%$ & $25.5 \%$ & $25 \%^{102}$ & $25 \%$ \\
\hline $\begin{array}{l}\text { Other notable taxes/ } \\
\text { contributions }\end{array}$ & & & $\begin{array}{l}\text { According to Impact Benefit } \\
\text { Agreement }\end{array}$ & & $\begin{array}{l}\text { Annual municipal tax on } \\
\text { industry properties: } 0-0.7 \% \\
\text { of property value }{ }^{103}\end{array}$ & \\
\hline
\end{tabular}

${ }^{96}$ Larger sum in case EIA is required.

${ }^{97}$ Smaller sum for exploration, handled by Directorate.

${ }^{98}$ Larger sum if meeting is required.

99 18\% in Faroe Islands.

${ }^{100}$ Additional surcharge of $6 \%$, bringing total to $31.8 \%$.

$10116 \%$ on Svalbard up to NOK 15 M.

$1020 \%$ on Svalbard.

${ }^{103}$ Optional for municipalities, may vary in size and what objects are taxed. 
Nordic Council of Ministers

Ved Stranden 18

DK-1061 Copenhagen K

www.norden.org

\section{Mining in the Nordic Countries}

The last few years have seen a lot of activity within the Nordic mining industry. New mines have opened, but there have also been cases of bankruptcies. Heightened activity has in turn led to discussions on the role of legislation and taxation in ensuring that mining contributes to sustainable development. At the same time, a number of voluntary sustainability initiatives have appeared.

For historic reasons, the Nordic countries share a lot of similarities with regards to legislation. And not least with regards to environmental laws, the EU has contributed to further harmonisation, even among the non-member states Iceland and Norway. Yet important differences exist. Legal revisions are sometimes the result of much-publicised problems, so experiences in each country plays an important role.

An overview of taxation also indicates both similarities and differences.

TemaNord 2015:542

ISBN 978-92-893-4232-2 (PRINT)

ISBN 978-92-893-4234-6 (PDF)

ISBN 978-92-893-4233-9 (EPUB)

ISSN 0908-6692

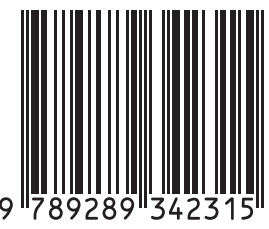

